\title{
Effects of Duct Improvement and ENERGYSTAR Equipment on Comfort and Energy Efficiency
}

\author{
PECEMPED \\ OCT 162200 \\ OSTI
}

I. Walker, M. Sherman, J. Siegel, and M. Modera

Environmental Energy Technologies Division

Energy Performance of Buildings Group

Lawrence Berkeley National Laboratory

Berkeley, CA 94720

July 1999

This study was sponsored by the U.S. Environmental Protection Agency, through the U.S.

Department of Energy under Contract No. DE-AC03-76SF00098. Publication of research results does not imply EPA endorsement of or agreement with these findings. 


\section{DISCLAIMER}

This report was prepared as an account of work sponsored by an agency of the United States Government. Neither the United States Government nor any agency thereof, nor any of their employees, make any warranty, express or implied, or assumes any legal liability or responsibility for the accuracy, completeness, or usefulness of any information, apparatus, product, or process disclosed, or represents that its use would not infringe privately owned rights. Reference herein to any specific commercial product, process, or service by trade name, trademark, manufacturer, or otherwise does not necessarily constitute or imply its endorsement, recommendation, or favoring by the United States Government or any agency thereof. The views and opinions of authors expressed herein do not necessarily state or reflect those of the United States Government or any agency thereof. 


\section{DISCLAIMER}

Portions of this document may be illegible in electronic image products. Images are produced from the best available original document. 


\section{Table of Contents}

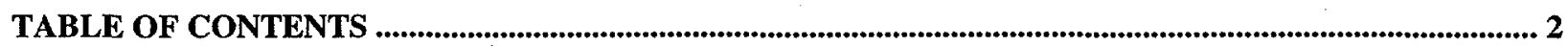

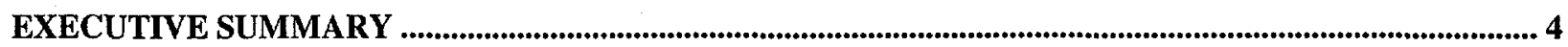

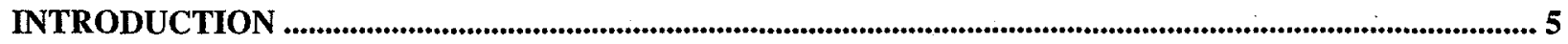

DUCT LEAKAGE AND ENERGYSTAR EQUIPMENT EFFECTS ON COMFORT .................................... 5

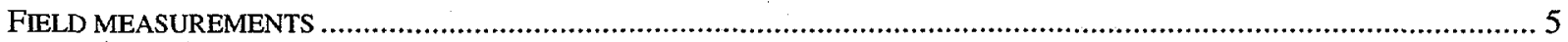

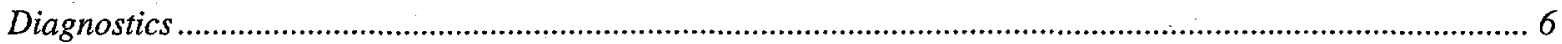

House ventilation rates.

Table 1. Summary of House Envelope Leakage Test Results .................................................................................... 7

Table 2. Summary of Tracer Gas Measurements of House Ventilation Rates .................................................................... 7

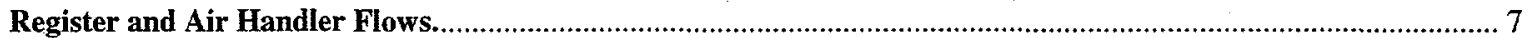

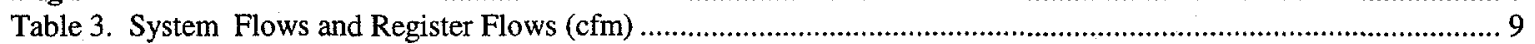

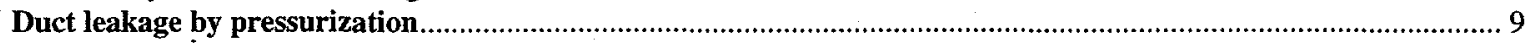

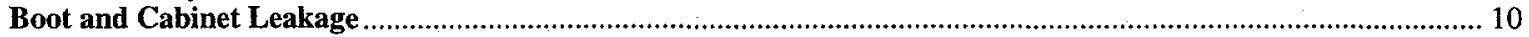

Table 4. Summary of Fan Pressurization Leakage Flows at $25 \mathrm{~Pa}(\mathrm{cfm} 25)$................................................................. 11

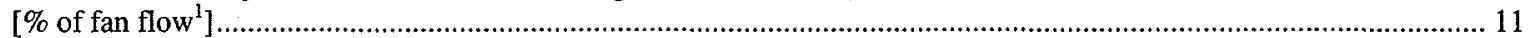

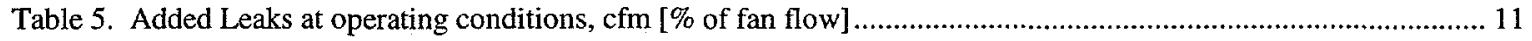

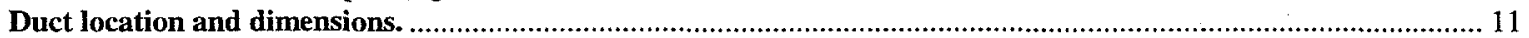

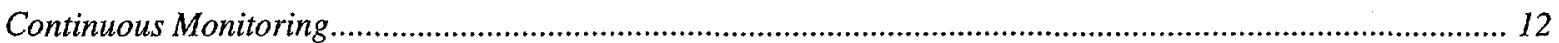

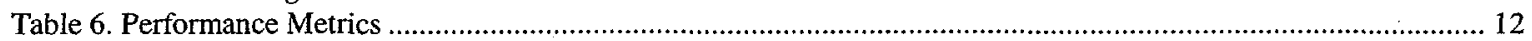

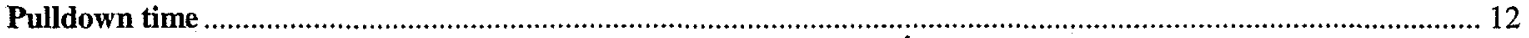

Temperature distribution.......................................................................................................................... 12

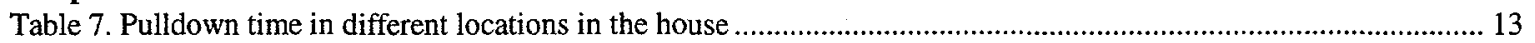

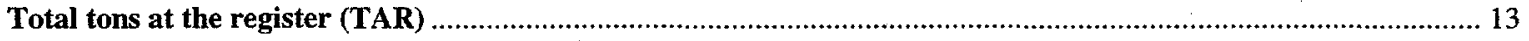

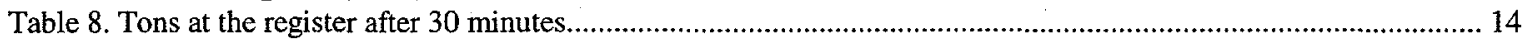

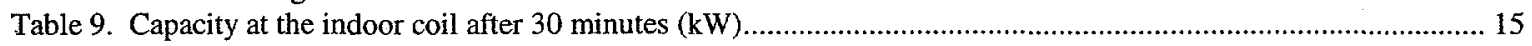

Comparing Measured and Rated Air Conditioner Capacity ........................................................................ 15

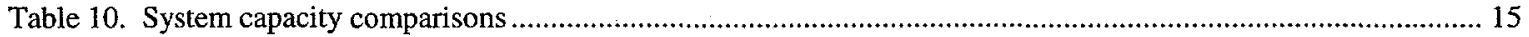

Air conditioner Coefficient of Performance (COP) ........................................................................................ 15

Table 11. Equipment Coefficient of Performance (COP), Power Consumption and fraction of power consumption due to

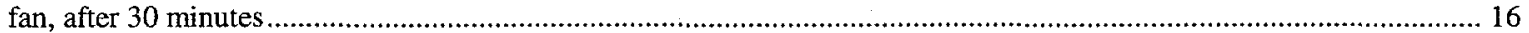

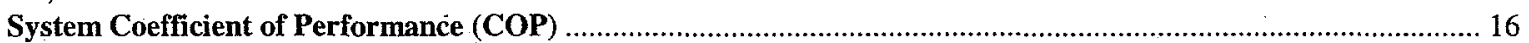

Table 12. Total System Coefficient of Performance (COP) after 30 minutes...................................................................... 17

Delivery Effectiveness (DE) ....................................................................................................................... 17

Table 13. Delivery Effectiveness [\%] after 30 minutes ............................................................................................ 17

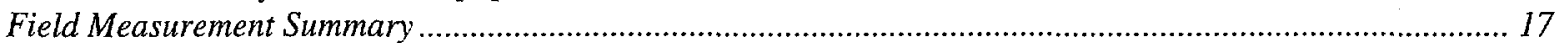

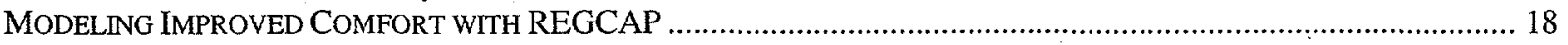

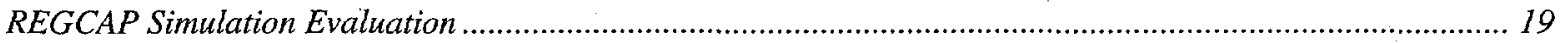

Figure 1: REGCAP Predicted and Measured Attic Temperatures for the Sacramento test house. August 11, 1998......... 20

Attic Temperature

Figure 2: REGCAP Predicted and Measured House Air Temperatures for the Sacramento test house. August 11, 199821

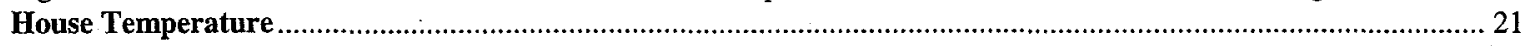

Figure 3: REGCAP Predicted and Measured Return Duct Air Temperatures for the Sacramento test house. August 11,

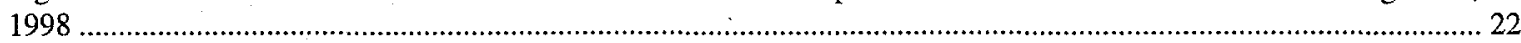

Return Duct Air Temperature.............................................................................................................. 22

Figure 4: REGCAP Predicted and Measured Supply Duct Air Temperatures for the Sacramento test house. August 11,

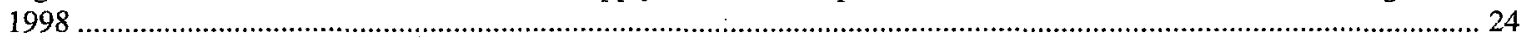

Supply Duct Air Temperature

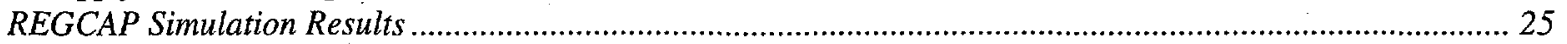


Figure 5. REGCAP Simulations of pulldowns from 3:00 p.m. on a Sacramento design day.

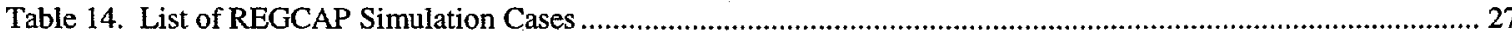

Table 15. REGCAP Delivered Capacity (TAR) Comparison (System on for 1.75 hours) ...........................................2 27

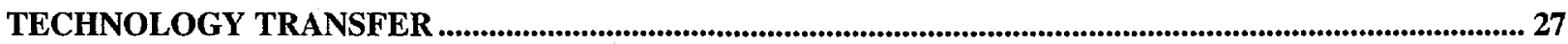

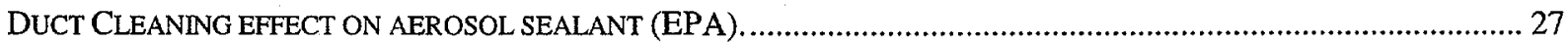

HEALTH AND SAFETY ASSESSMENT OF AEROSOL SEALANT (EPA) ........................................................ 28

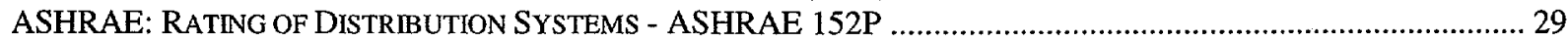

ASTM: RATING OF DUCT SEALANTS AND REVISING DUCT LEAKAGE MEASUREMENT METHODS........................29

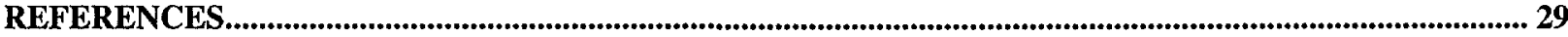

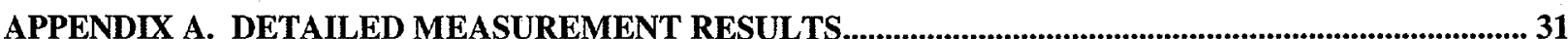

Table A1. Pulldown time and temperatures in different locations in the house ..........................................................31

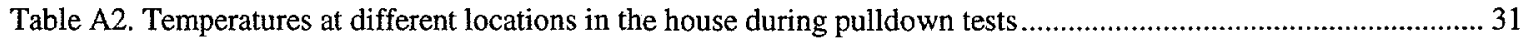

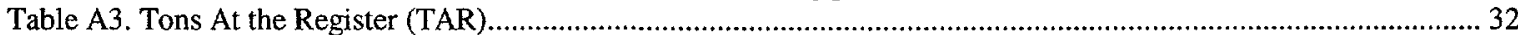

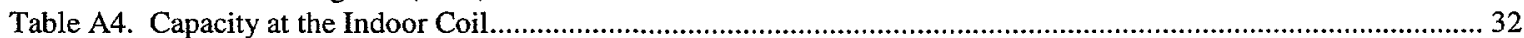

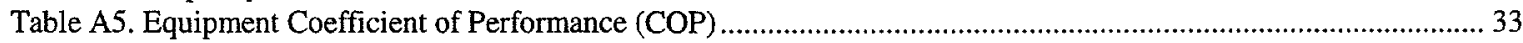

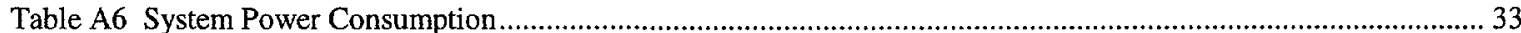

Table A7. Total System Coefficient of Performance (COP)

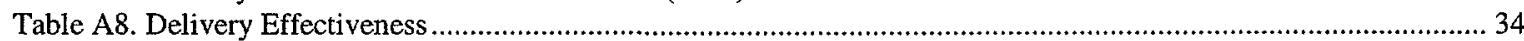

Table A9 Key Temperatures and Enthalpies for Calculating System Performance .................................................. 34

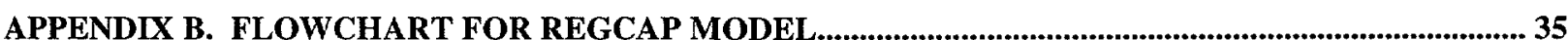




\section{Executive Summary}

This report discusses the results of field tests and computer simulations to evaluate and parameters that influence energy efficiency and comfort of forced air cooling systems. The field study was performed in two houses: one in Sacramento, CA., and one in Cedar Park, TX. The two house locations were chosen to represent a relatively dry cooling climate and a high humidity cooling climate respectively. The two houses were tested with standard SEER 10 Air Conditioning equipment and then with ENERGYSTAR equipment (SEER 13). The field testing combined continuous monitoring of system performance with diagnostic tests of the house and HVAC system. The system performance was evaluated in terms of effective capacity (both latent and sensible), equipment and system efficiency, pulldown time room-to-room temperature distribution. Because the weather was cool during the testing in Cedar Park, the following results focus on the Sacramento test results.

The key results discussed in this report include:

- Poor duct system design and installation significantly affects comfort. An example is the associated room-toroom temperature differences.

- The SEER rating was a reasonable numerical guide to Air Conditioner efficiency ${ }^{1}$.

- Air conditioner name plate capacity ratings alone are a poor indicator of how much cooling will actually be delivered to the conditioned space. Duct system efficiency can have as large an impact on performance as variations in SEER.

- Duct leakage added approximately 0.2 Air Changes per Hour to the house infiltration rate during system operation.

- The REGCAP computer simulation showed that it was capable of modeling the dynamic performance of forced air thermal distribution systems.

- The REGCAP simulations showed how improving duct efficiency can allow the use of smaller capacity air conditioning equipment.

\footnotetext{
${ }^{1}$ For sensible effects only.
} 


\section{Introduction}

Residential thermal distribution systems have significant energy and comfort implications due to losses from the distribution system in the form of leakage and conduction and poor distribution from room-to-room within the house. Also, poor mechanical equipment performance, and the interactions between the distribution system and the equipment act to further reduce system capacity and thermal comfort. An example of duct system and equipment interaction is the that airflow over the indoor coils changes the efficiency, capacity and humidity removal of the system resulting in comfort, energy consumption and efficiency changes. To determine if there are any differences in the interactions depending on whether or not the equipment is ENERGYSTAR rated, two houses were tested with standard (SEER10) air conditioners and then retrofitted with ENERGYSTAR (SEER 13) equipment. In addition, the effect of duct leakage was examined by adding leaks to the systems under test. The original plan had been to seal the duct systems, but they were found to be not very leaky. Leakage was added in order to show the effect of reduced leakage. Four additional houses were tested as part of a companion study (Walker et al. (1999)) that did not have equipment changes. Selected measurement results from these houses are presented where appropriate.

This report is in two main parts. The first part discusses the field measurement techniques and results. The second part examines efforts to model distribution system performance using a sophisticated computer simulation program called REGCAP. REGCAP has been developed to specifically include the interactions of duct systems with their surroundings (In this study the duct surroundings are attic spaces). Lastly, a brief summary of related thermal distribution system research is included at the end of the report.

\section{Duct Leakage and ENERGYSTAR Equipment Effects on Comfort}

Three key concepts related to comfort were used to study this issue:

1. Tons at the Register (TAR). Tons at the register is the actual cooling delivered to the conditioned space, i.e. what comes out of the registers. The combined distribution system losses and system capacity at operating conditions act to determine the TAR of a system.

2. Pulldown. Comfort, and hence occupant acceptability, is determined not only by steady-state temperatures, but by how long it takes to pull down the temperature during cooling start-up, such as when the occupants come home on a hot summer afternoon. In addition, the delivered tons of cooling at the register during start-up conditions are critical to customer acceptance of equipment downsizing strategies. In this study, the pulldown was evaluated at different locations within the house to evaluate thermal comfort issues regarding distribution of cooling within the house.

3. Room-by-room temperature distribution. A well designed and installed system accounts for variations in roomby-room loads by having the appropriate flow through each register in each room. Poor systems have incorrect flows through their registers resulting in room-to-room temperature differences. From a comfort point of view, some occupants may not be happy because some rooms will be either too cool or too hot. From an energy perspective, this is also poor because to have all occupied parts of the house cooled to a comfortable level (particularly upstairs room sin two-story houses) some parts of the house will be much cooler than necessary. Energy has then been wasted by overcooling parts of the house.

\section{Field measurements}

Field measurements were made on air-conditioning systems in two new and unoccupied houses: one in Sacramento, CA., and the other in Cedar Park, TX. The two house locations were chosen to represent a relatively dry cooling climate and a high humidity cooling climate, respectively. The measurements included diagnostics to determine building and system characteristics and continuous monitoring over several days to determine system performance. The Sacramento house was cooled with a split system air conditioner and heated with natural gas (using the same air handler/cabinet and ducts). The Texas house had a heat pump and electric resistance strip heat. The Sacramento 
house had all of the system in the attic - air handler, equipment cabinet and ducts. The Cedar Park house had the air handler/cabinet in a closet in the house, with only the supply plenum and supply ducts in the attic. The "return" duct in this house was the space under the platform that supported the air handler cabinet. A large grille was placed through the platform wall below the closet door. Flow was somewhat restricted in this system despite its simplicity because the water heater was located within the air-handler platform!

The houses were tested in their "as found" configuration and with holes added to the duct systems. The original plan was to test systems in the "as found" condition and then seal the duct systems, however the duct systems in the two test houses were not very leaky in the "as found" condition. Therefore holes were added instead to enable us to still examine the effect of leakage on system performance. The holes were added at the system plenums because these locations provided easy access and large flat areas for placing the holes. The added holes varied in size from system to system, but they were typically four inches $(10 \mathrm{~cm})$ in diameter. At both test houses an attempt was made to measure the flow through the added holes directly, rather than inferring the leakage flow from indirect measurements as used in standard diagnostic tests. At the Sacramento test house, the airflow through these added holes was measured using a vane anemometer during normal system operation. At the Texas house, the holes were calibrated in a laboratory. The airflow was then determined by measuring the pressure difference across the holes at the hole location during normal system operation.

When the ENERGYSTAR equipment was installed in Sacramento, just the outside compressor unit and the control system were changed. In the Cedar Park house the indoor coil, fan and cabinet (and electric heating system) were also replaced. In each case the nominal nameplate capacity was the same for both the original and ENERGYSTAR equipment.

The continuous monitoring was performed for several days in each system configuration. During this monitoring the system was set to stay off until about 3:00 p.m., allowing the house to warm up during the day. Then the system was turned on and the house temperature was "pulled down" to $74^{\circ} \mathrm{F}\left(24^{\circ} \mathrm{C}\right)$ at the thermostat. Because temperatures were monitored in each room we were able to determine if the temperature at the thermostat was representative of other temperatures in the house. In most cases, the thermostat was not the warmest place in the house (it was usually centrally mounted in a hallway away from any direct solar gains) and so the pulldown was changed to reduce the temperature at the thermostat below the original $74^{\circ} \mathrm{F}\left(24^{\circ} \mathrm{C}\right)$ setpoint. The reduced thermostat pulldown temperature setpoint was varied for each test, depending on the specific temperature differences between the rooms and the thermostat and the weather conditions on the day of the test. In addition, pulldown times were calculated for different parts of the house.

\section{Diagnostics}

The following diagnostics were used to characterize the house and duct system and determine changes in system performance (e.g., effect of added leaks on system flows). Also, the results of the diagnostics were used as input parameters to the REGCAP simulations.

\section{Envelope Leakage.}

The envelope leakage was measured using a blower door test with the registers uncovered. Therefore, it includes leakage to outside via the duct system. The envelope leakage for the test houses is given in Table 1. The leakage is expressed in three ways:

- in terms of the blower test results, i.e., the flow coefficient and pressure exponent,

- Specific Leakage Area (SLA), and

- flow at $50 \mathrm{~Pa}$ divided by floor area (Q50/FA).

The SLA and Q50/FA are methods of scaling leakage by house size so that comparisons of envelope air tightness can be made between houses. In addition, the calculation of SLA allows the comparison of these houses to a "standard" house that would meet California Energy Code (California Energy Commission (1998)). Both these methods normalize the leakage by house floor area. SLA uses the effective leakage area (defined at 0.016 in. of water $(4 \mathrm{~Pa})$ with a discharge coefficient of 1.0) of the house calculated from the flow coefficient and pressure exponent. These houses had SLAs typical of new construction that were close to the California Energy Code default SLA of 4.9 for houses with ducted forced air systems. Q50 uses the flow coefficient and the pressure exponent to calculate the envelope flow at 0.2 in. of water $(50 \mathrm{~Pa})$, i.e. $\mathrm{Q} 50=\mathrm{C}(50)^{\mathrm{n}}$. 


\section{House ventilation rates.}

Ventilation rates were measured using tracer gas decay with the system fan off and with the system fan on. The differences between fan on and fan off results were used to determine any changes in ventilation rate due to duct leakage. The results of these tests are summarized in Table 2. Because of the large variation in ventilation rates with weather conditions, the only significant result is the change in ventilation rate due to system operation. This is because the ON/OFF tests took two to three hours to perform and the change in weather driven infiltration over that time period is usually less than day to day variations. The fractional increases (compared to when the system was off) in ventilation due to system operation are only valid for the particular instances of these tests. For example, the large fractional increase at Cedar Park after holes were added is because the ventilation rate was very low with the system off. However, the results shown in Table 2 show that the system operation does have a significant effect on the ventilation rate - adding an average of 0.2 Air Changes per Hour (ACH). Previous studies found similar results, with the infiltration rate doubling when the system is turned on (see Cummings et al. (1990), Palmiter and Francisco (1994), Palmiter and Bond (1992) and Modera (1989)).

Table 1. Summary of House Envelope Leakage Test Results

\begin{tabular}{|c|c|c|c|c|}
\hline Site & $\begin{array}{c}\text { Leakage } \\
\text { Coefficient, } \mathrm{C} \\
\left(\mathrm{cfm} / \mathrm{Pa}^{\mathrm{n}}\right)\end{array}$ & $\begin{array}{c}\text { Pressure } \\
\text { Exponent, } \mathrm{n}\end{array}$ & SLA & $\begin{array}{c}\text { Q50/floor area } \\
\left(\mathrm{cfm} / \mathrm{ft}^{2}\right)\end{array}$ \\
\hline $\begin{array}{c}\text { Sacramento, } \\
\text { CA }\end{array}$ & 110 & 0.64 & 6 & 1.61 \\
\hline $\begin{array}{c}\text { Cedar Park, } \\
\text { TX }\end{array}$ & 243 & 0.59 & 5.2 & 1.40 \\
\hline
\end{tabular}

Table 2. Summary of Tracer Gas Measurements of House Ventilation Rates

\begin{tabular}{|c|c|c|c|c|}
\hline Site & $\begin{array}{c}\text { Fan } \\
\text { Mode } \\
\text { (off/on) }\end{array}$ & $\begin{array}{c}\text { Building } \\
\text { Ventilation } \\
\text { rate }(\mathrm{ACH})\end{array}$ & $\begin{array}{l}\text { ACH Change (fan } \\
\text { ON - OFF) }\end{array}$ & $\begin{array}{l}\mathrm{ACH} \text { fan on as multiple of } \mathrm{ACH} \\
\text { fan off }\end{array}$ \\
\hline \multirow{2}{*}{$\begin{array}{l}\text { Sacramento. } \\
\text { As Found }\end{array}$} & ON & 0.41 & \multirow[t]{2}{*}{0.18} & \multirow[t]{2}{*}{1.8} \\
\hline & OFF & 0.23 & & \\
\hline \multirow{2}{*}{$\begin{array}{l}\text { Cedar Park. } \\
\text { As Found }\end{array}$} & ON & 0.25 & \multirow[t]{2}{*}{0.12} & \multirow[t]{2}{*}{1.9} \\
\hline & OFF & 0.13 & & \\
\hline \multirow{2}{*}{$\begin{array}{c}\text { Cedar Park. } \\
\text { Added Leaks }\end{array}$} & ON & 0.45 & \multirow[t]{2}{*}{0.37} & \multirow[t]{2}{*}{5.6} \\
\hline & OFF & 0.08 & & \\
\hline
\end{tabular}

\section{Register and Air Handler Flows.}

The supply register flows were measured using a fan assisted flowhood. The return register flows were measured either using a flowhood or a vane anemometer traverse. The mean anemometer velocities were combined with an estimate of the open area of the return grille to obtain return flows. The sums of the register flows are summarized in Table 3. 
All the fan flow results are summarized in Table 3. The fan flows were estimated using three techniques:

1. Fan flowmeter operating pressure matching.

2. Tracer gas concentration.

3. Combining register flows and leakage measurements.

\section{Fan flowmeter:}

The fan flowmeter test methods used here are based on those in proposed ASHRAE Standard 152P (ASHRAE 1999) and the procedure in Alternative Calculation Manual, Appendix F of the Energy Efficiency Standards for Low-Rise Residential Buildings (California Energy Commission (CEC), (1998)) (often referred to as Title 24). This test uses the supply ducts as a flowmeter and utilizes the fact that having the same pressure drop across the supply system at operating conditions and measurement conditions ensures the same flow through the system at the two different conditions. The pressure difference between the supply plenum and the conditioned space is measured at normal operating conditions. The return duct is then blocked off from the rest of the equipment and a combined fan and flowmeter attached at the air handler access. The fan flowmeter is turned on and adjusted until the pressure difference between the supply plenum and the conditioned space is the same as at normal operating conditions. The flow through the flowmeter is then the system fan flow at operating conditions. However, the fan flowmeter does not usually produce enough flow to match the supply plenum to conditioned space operating pressure. In these cases the fan flowmeter is operated at maximum output and the flow and supply plenum to conditioned space pressure are recorded. Assuming a pressure exponent of 0.6 for the duct system, the measured flow at maximum output is extrapolated to the flow at the operating condition pressure difference.

An alternative is to operate the fan flowmeter over a range of flows, recording the flows and supply plenum to conditioned space pressure differences. A least squares fit can then be used to determine a flow coefficient, and pressure exponent for the system and the flow at operating condition pressures is determined from these parameters.

For this fan flow measurement technique one source of error is possible changes in flow patterns in the plenum and duct system, such that the flow through the system when the pressures are matched (or extrapolated to) is not the same as at normal operating conditions. Another source of error is in mounting the fan flowmeter such that the outlet is partially blocked (this is typical if the fan flowmeter is attached directly to the air handler cabinet). This blocking of the outlet changes the flowmeter calibration such that the flowmeter can give significantly incorrect readings. We (and other researchers) are continuing to examine this issue in ongoing work.

\section{Tracer gas:}

The tracer gas method uses a mass flow meter to release a tracer gas a fixed known rate in to the return grille. The tracer gas concentration is measured at a supply register and the flow rate calculated from the tracer gas concentration. The biggest problem with this test method is the requirement that the tracer as be thoroughly mixed in the supply ducts. In the tests for this study we measured the tracer gas concentrations at several registers (typically four or five) to check for complete mixing (measuring the same concentration at each register confirms the mixing).

\section{Combining supply register flows and pressurization leakage results:}

In this method the sum of the register flows from the flowhood measurements is added to the measured supply duct leakage taken from pressurization duct leakage tests to determine flow through the system fan. The sum of the supply register flows was $15 \%$ less than the fan flow for Sacramento and $17 \%$ less than the fan flow for Cedar Park. Note that not all of this difference is leakage directly to outside - the fraction of leakage to outside will discussed later in the duct leakage measurements section. 


\section{Table 3. System Flows and Register Flows (cfm)}

\begin{tabular}{|c|c|c|c|c|c|}
\hline & \multicolumn{3}{|c|}{ Fan flow Measurement Method } & \multicolumn{2}{|c|}{ Sum of register flows } \\
\hline Site Configuration & $\begin{array}{l}\text { Tracer } \\
\text { Gas }\end{array}$ & Using Flow meter & $\begin{array}{l}\text { Sum of Supply } \\
\text { Register Flows } \\
\text { Plus Supply } \\
\text { Duct Leakage }\end{array}$ & Supply & $\begin{array}{l}\text { Return (Traverse or } \\
\text { Flow } \underline{\text { Hood) }}\end{array}$ \\
\hline Sacramento - as found & 1205 & $\begin{array}{l}1210 \text { (F Flow meter)* }^{*} \\
1361 \text { (S flow meter)** }\end{array}$ & 1104 & 1004 & Not performed \\
\hline $\begin{array}{l}\text { Sacramento - added } \\
\text { leaks }\end{array}$ & 1240 & $\begin{array}{l}1021 \text { (F flow meter) } \\
1231 \text { ( } \mathrm{S} \text { flow meter) }\end{array}$ & 1082 & 928 & $828(\mathrm{H})$ \\
\hline Cedar Park -as found & None & $\begin{array}{l}1408 \text { (F flow meter) } \\
1614 \text { (S flow meter) } \\
1415 \text { (S HVAC) }\end{array}$ & 1448 & 1336 & $1492(\mathrm{~T})$ \\
\hline $\begin{array}{l}\text { Cedar Park - with } \\
\text { ENERGYSTAR } \\
\text { equipment }\end{array}$ & None & $\begin{array}{l}1488 \text { (F flow meter) } \\
1664 \text { (S flow meter) }\end{array}$ & 1499 & 1430 & $1543(\mathrm{~T})$ \\
\hline $\begin{array}{l}\text { Cedar Park - added } \\
\text { leaks - with } \\
\text { ENERGYSTAR } \\
\text { EQUTPMENT }\end{array}$ & None & 1697 (F Flow meter) ${ }^{* * *}$ & 1559 & 1458 & $1415(\mathrm{~T})$ \\
\hline
\end{tabular}

* $-F$ tests are fits to data points with a forced intercept of 0 flow at 0 pressure.

** $-S$ tests use highest measured flow and pressure and extrapolate to operating conditions $(n=0.6)$

${ }^{\star \star \star}$ Flow meter mounted at the return grille, flows were corrected for estimated return and cabinet leakage.

\section{Duct leakage by pressurization}

For these tests the registers are covered and a fan flowmeter is attached to the duct system to pressurize it. The flow is measured at a reference pressure of $25 \mathrm{~Pa}$ and is referred to as $\mathrm{cfm} 25$. Duct leakage by pressurization can be separated into five components: supply, supply boot, return, return boot and cabinet. This was done by connecting the fan flowmeter at different parts of the duct system and inserting blocking in the ducts to isolate the individual components. For example the test method used to determine supply boot leakage has the following steps:

- The supply and return are split by blocking the supply from the return within the equipment cabinet.

- The total supply leakage is then found by covering the supply registers and pressurizing the supply ducts (this determines the combined supply duct and supply boot leakage).

- The registers are then removed and a blockage is placed inside each register upstream of the boot. The supply ducts are then pressurized again to determine the duct only leakage.

- The boot leakage is the difference between these two tests.

Note that in these houses the return boot leakage was not separated out from the total return leakage due to the construction of these systems. In Sacramento, the filter was at the single return grille and so the return boot was depressurized to the same level as the rest of the return system. In addition, it was very difficult to put separators in place to isolate just the leaks around the return grille connection to the return (effectively the return boot in this case). In Cedar Park, there was no return duct - just a grille into side of a platform and therefore no return boot to isolate.

The separation of total leakage from leakage to outside was accomplished by simultaneously pressurizing the house with a blower door to the same pressure (referenced to outside) as the duct system. This means that there will be zero (or a very small) pressure across any leaks from the duct system to inside and only duct leakage to outside will be measured. At Cedar Park, there was significant return leakage to outside, although there were no return ducts as such. This was because the closet containing the equipment and the platform return leaked to the attic through holes around the ceiling penetration for the supply plenum. This shows the necessity for field testing of duct systems 
because simple observation would have implied that the return leaks were to the closet (essentially the conditioned space).

The complete pressurization test results are given in Table 4. The system fan flow used to normalize the test results is the single point extrapolated fan flowmeter measurement (the $-S-$ test in Table 3 ). The exception in the final test at Cedar Park (with added leaks and the ENERGYSTAR equipment) where the system fan flow is the flowmeter - F test. The Sacramento house had a total (combining boots cabinet and ducts leakage to outside) $\mathrm{cfm} 25$ of $11 \%$ of fan flow. This was increased to $29 \%$ of fan flow by adding the holes. The "as found" leakage to inside was about a quarter of the magnitude of the leakage to outside. For the Cedar Park house the "as found" $\operatorname{cfm} 25$ was $7 \%$ of fan flow and $20 \%$ with the added holes. The as found leakage to inside was about the same as the leakage to outside. In the "as found" condition, these systems were less leaky than the $22 \%$ of fan flow for new California houses from previous studies by Walker at al. $(1997,1998 \mathrm{~b})$ and by Modera and Wilcox (1995).

The original plan was to tighten leaky duct systems to examine the effect of duct leakage. However, the ducts in these houses gave little scope for reducing leakage by sealing, so both sites had leakage added. The added leaks were cut into the supply and return plenums and resealed after the experiments were finished. The added leakage flows were individually measured at operating conditions, as well as using the pressurization technique. At Cedar Park the leakage flows at operating conditions were measured directly using a vane anemometer. The added holes were cut precisely to be the same size as the vane anemometer so that no traverses and interpolations were required. At Sacramento the extra leaks were calibrated in a laboratory and the measured system operating pressures were used to estimate the leakage flows at operating conditions. These added leaks are summarized in Table 5.

\section{Boot and Cabinet Leakage}

A key question raised in previous duct leakage measurements was the contribution of leaks at boots and the HVAC equipment cabinet to the total duct leakage. These two parts of the duct system were examined separately because they represent opportunities for duct system leakage reduction that can be fixed by changes in the manufacture of equipment and by boot inspection and sealing without great expense or effort for the installer/builder. The cabinet leaks include the connection from the cabinet to the plenums, but not the duct connections to the plenums. These cabinet leaks are of particular interest because it should be relatively simple to eliminate these leaks with a combination of changes to cabinet construction (tighter tolerances and improved fan access door seals) and more attention paid to filling knockouts with grommets. Although changing the manufacturing process for system cabinets may initially be costly for manufacturers, the significant cabinet leakage means that it has a large potential added value in terms of energy savings and comfort.

The results in Table 4 show that cabinet leakage averaged $24 \mathrm{cfm} 25$ to outside. The supply boots averaged about 40 $\mathrm{cfm} 25$ to outside. Assuming a pressure exponent of 0.6 and converting these results to the average of the measured operating pressures of about $5 \mathrm{~Pa}$ for boots and $65 \mathrm{~Pa}$ for cabinets results in boot leakage of about $15 \mathrm{cfm}$ and cabinet leakage of about $43 \mathrm{cfm}$. At both sites, the boot and cabinet leakage was a substantial fraction (25\%-50\%) of the "as found" duct leakage to outside. This means that achieving high levels of air-tightness in ducts (e.g., the leakage requirements for the efficient duct credit in California State Energy Code (CEC (1998))) will require boot and cabinet leaks to be sealed and not just leaks in the ducts themselves. 


\begin{tabular}{|c|c|c|c|c|c|c|}
\hline \multicolumn{7}{|c|}{$\begin{array}{c}\text { Table 4. Summary of Fan Pressurization Leakage Flows at } 25 \mathrm{~Pa}(\mathrm{cfm} 25) \\
{\left[\% \text { of fan flow }{ }^{1}\right]}\end{array}$} \\
\hline \multicolumn{7}{|c|}{ Sacramento } \\
\hline $\begin{array}{l}\text { Leakage } \\
\text { condition }\end{array}$ & & Supply & Supply Boots & $\begin{array}{c}\text { Return } \\
+ \text { Return Boots }\end{array}$ & Cabinet & Total \\
\hline \multirow[t]{2}{*}{ As found } & Total & $26[2]$ & $92[7]$ & $38[3]$ & $26[2]$ & $182[13]$ \\
\hline & To Outside & $24[2]$ & $63[5]$ & $24[2]$ & $26[2]$ & $137[10]$ \\
\hline \multirow[t]{2}{*}{ Added Holes } & Total & 145 [12] & $92[7]$ & 134 [11] & $26[2]$ & $397[32]$ \\
\hline & To Outside & $118[10]$ & $63[9]$ & $96[8]$ & $26[2]$ & 303 [25] \\
\hline \multicolumn{7}{|c|}{ Cedar Park } \\
\hline $\begin{array}{l}\text { Leakage } \\
\text { condition }\end{array}$ & & Supply & Supply Boots & $\begin{array}{c}\text { Return }+ \\
\text { return Boots }\end{array}$ & Cabinet & T otal \\
\hline \multirow[t]{2}{*}{ As found } & Total & $40[2]$ & $33[2]$ & $163[10]$ & $22[1]$ & $258[16]$ \\
\hline & To Outside & $36[2]$ & $21[1]$ & $51[3]$ & $5[1]$ & $113[7]$ \\
\hline \multirow{2}{*}{$\begin{array}{c}\text { With } \\
\text { ENERGYSTAR } \\
\text { equipment }\end{array}$} & Total & $40[2]$ & $33[2]$ & $163[10]$ & $22[1]$ & $258[16]$ \\
\hline & To Outside & $36[2]$ & $21[1]$ & $51[3]$ & $42[3]$ & $150[9]$ \\
\hline \multirow{2}{*}{$\begin{array}{l}\text { Added leaks - } \\
\text { with } \\
\text { ENERGYSTAR } \\
\text { equipment }\end{array}$} & Total & $101[6]$ & $33[2]$ & 322 [19] & $22[1]$ & $478[28]$ \\
\hline & To Outside & $\mathrm{n} / \mathrm{a}$ & $\mathrm{N} / \mathrm{a}$ & $n / a$ & $42[3]$ & \\
\hline
\end{tabular}

\begin{tabular}{|c|c|c|}
\hline \multicolumn{3}{|c|}{ Table 5. Added Leaks at operating conditions, cfm [\% of fan } \\
flow]
\end{tabular}

\section{Duct location and dimensions.}

At Sacramento, the entire system of air handler, furnace, cooling coils and supply ducts were all in the attic. At Cedar Park, the air handler and equipment were in a closet inside the thermal envelope of the house, with the supply ducts in the attic. The return was a simple stand that was part of the closet containing the air handler. The duct surface areas were estimated by measuring each duct run length and exterior dimensions with a measuring tape. At Sacramento there was $22.5 \mathrm{~m}^{2}\left(243 \mathrm{ft}^{2}\right)$ of exposed supply ducts and $7 \mathrm{~m}^{2}\left(276 \mathrm{ft}^{2}\right)$ of return ducts. At Cedar Park there was $30.4 \mathrm{~m}^{2}\left(327 \mathrm{ft}^{2}\right)$ of supply ducts and no return duct in the attic. 


\section{Continuous Monitoring}

The continuous monitoring used computer based data acquisition systems to store data about every 10 seconds. The monitored parameters were:

- Temperatures at each register, in each room, outdoors, attic, garage, return plenum and supply plenum. The supply plenum temperatures were measured at four points in the plenum to account for possible spatial variation in plenum temperatures.

- Weather: wind speed, wind direction, total solar radiation and diffuse solar radiation.

- Humidity: outside, supply air, return air and attic.

- Energy Consumption: Compressor unit (including fan) and distribution fan power.

The measured system temperatures and relative humidities were combined with the register and system fan flow rates used to calculate the energy flow for each register (tons at each register) and the energy change of the air stream at the heat exchanger. The supplies were then combined to find the total energy flow (Tons At the Register, or TAR) for the system.

The performance metrics that were calculated from the measured data are listed in Table 6. Except for pulldown time and temperature distribution, each metric has a sensible and a latent component (reported as a sensible and total). For all of the metrics except the pulldown time, the value is reported from an average of a minute of data at 5 , 30 , and 60 minutes from when the pulldown test began. This range of times was used because of the significant transient changes in system performance between the beginning of a cycle and the quasi-steady-state operation reached later in the pulldown test.

\begin{tabular}{|l|l|}
\hline \multicolumn{2}{|c|}{ Table 6. Performance Metrics } \\
\hline Pulldown Time and Temperature Variattion & $\begin{array}{l}\text { Time that it takes for a location within the house to reach } \\
24^{\circ} \text { C. Three pulldown times are reported: for the } \\
\text { thermostat (how the system house would normally } \\
\text { respond), kitchen, and master bedroom. A wide } \\
\text { disparity between these times indicates an inadequate } \\
\text { distribution system. }\end{array}$ \\
\hline Tons at the register (TAR) & $\begin{array}{l}\text { Capacity of the air conditioner calculated from } \\
\text { temperatures and relative humidities measured in the } \\
\text { supply and return plenums and air handler flow. }\end{array}$ \\
\hline Air Conditioner Capacity & $\begin{array}{l}\text { Air conditioner capacity divided by power consumed by } \\
\text { air conditioner, including fan energy }\end{array}$ \\
\hline Air Conditioner Coefficient of Performance (COP) & $\begin{array}{l}\text { Tons at the register divided by power consumed by air } \\
\text { conditioner, including fan energy }\end{array}$ \\
\hline System COP & Tons at the register divided by air conditioner capacity \\
\hline Delivery Efficiency &
\end{tabular}

\section{Pulldown time}

Pulldown time was significantly reduced by changing the equipment to ENERGYSTAR specifications, as shown in Table 7. The addition of leaks to the system increased the pulldown times in Sacramento. However, in Cedar Park, the added leakage measurements were performed under much milder weather conditions that resulted in very short pullown times. The Cedar Park result shows how the pulldown times are sensitive to changes in weather conditions. At Sacramento, the weather conditions were similar for all three tested conditions.

\section{Temperature distribution}

The temperature distribution showed significant room-to-room variations in the test houses and will be discussed here in terms of how it changes the pulldown time for each room as well as individual room to room temperature differences. Both test houses showed considerable variation (on the order of factors of two or more between the 
thermostat and master bedroom) in pulldown time for each of the three reported locations: thermostat, kitchen, and master bedroom. For the Sacramento house, the pulldown took longest at the thermostat - resulting in the other rooms being cooled too much (for more details see Appendix A, Tables A1 and A2). For the Cedar Park house, the master bedroom cooled much faster than the other rooms and was cooled too much (about $3^{\circ} \mathrm{C}\left(6^{\circ} \mathrm{F}\right)$ below the thermostat setpoint) by the time that the thermostat turned off the air conditioning system. In addition, the pulldown for each room depends on the temperatures in each room at the start of the pulldown. For example, the Cedar Park house, the master bedroom was about $2^{\circ} \mathrm{C}\left(4^{\circ} \mathrm{F}\right)$ hotter than the thermostat at the start of the pulldown. The combination of high start temperature and rapid pulldown for this room indicates that this room has too large a fraction of the overall system capacity delivered to it. This indicates that there are large imbalances in the air distribution for this house.

Other houses examined as part of a concurrent study (that did not have ENERGYSTAR systems installed, see Walker et al. (1999)) showed similar large variations, but with different rooms cooling slower than the thermostat location. For example, a two-story house in Mountain View, CA. had very poor distribution, particularly upstairs to the master bedroom. The upper floor of this house had a significantly increased load due to a skylight as well as an inadequate return system (there was no return from upstairs). The pulldown time at the thermostat (located downstairs) was less than half an hour, but the upstairs took another hour and a half to pulldown to the same temperature. When the thermostat had reached the pulldown temperature upstairs was $3^{\circ} \mathrm{C}\left(6^{\circ} \mathrm{F}\right)$ hotter than downstairs.

\begin{tabular}{|l|c|c|c|}
\hline \multicolumn{5}{|c|}{ Table 7. Pulldown time in different locations in the house } \\
\hline & \multicolumn{3}{|c|}{ Pulldown Time (minutes) } \\
\hline Site and test conditions & Thermostat & Master Bedroom & Kitchen \\
\hline Sacramento, as found & 239 & 122 & 198 \\
\hline $\begin{array}{l}\text { Sacramento, as found, } \\
\text { ENERGYSTAR Equipment }\end{array}$ & 159 & 64 & 107 \\
\hline $\begin{array}{l}\text { Sacramento, Leaks added, } \\
\text { ENERGYSTAR Equipment }\end{array}$ & 170 & 75 & 92 \\
\hline Cedar Park, as found & 257 & 93 & 266 \\
\hline $\begin{array}{l}\text { Cedar Park, as found, } \\
\text { ENERGYSTAR Equipment }\end{array}$ & 118 & 20 & 123 \\
\hline $\begin{array}{l}\text { Cedar Park, Leaks added, } \\
\text { ENERGYSTAR Equipment }\end{array}$ & 94 & 8 & 75 \\
\hline
\end{tabular}

\section{Total tons at the register (TAR)}

TAR was often negative when the air conditioner first came on because the hot air inside the duct system was blown into the house. This rapid initial change in temperature (a rapid initial increase followed by a gradual cooling further into the cycle) made analysis of the data for the five minute mark difficult because of the response time of the sensors. The response time of the temperature sensors is rapid enough that any time response errors are insignificant. However, the slower response of the RH sensors increases the uncertainty in the transient latent (and therefore total) TAR estimates. Because this time response issue can drive the results high or low depending on the particular operating conditions, it is not possible to estimate a generalized effect that would apply to all the measurements (i.e. a bias), instead it simply adds to the uncertainty of the latent TAR calculations during the start of each cycle. For example, one possibility is that the time lag of the RH sensor compared to the temperature sensor means that the measured RHs are higher than they actually are (assuming a reduction in moisture content of the air due to condensation on the coil) which leads to an underprediction of the latent TAR. Alternatively, if there is no moisture removal by the air conditioner, the $\mathrm{RH}$ of the air at the register should rise as the temperature drops. The longer time response of the RH sensors means that they read artificially low and this overpredicts the TAR, i.e., it gives the appearance of moisture removal without there being any. Because of these measurement problems, most of the comparisons made in this report are based on the 30 minute value when the air conditioner is operating close to a 
steady state condition.

The mean TAR measurements after 30 minutes are given in Table 8. The total TAR for Sacramento before the EnergyStar equipment was installed is not shown due to problems with the relative humidity measurements. Comparing the "as found" to "added leak" results does not clearly show any benefit to sealing the leaks. This is due to the limited number of tests and the variable weather during the tests. Table 8 also compares the measured TAR with the nominal (or nameplate) capacity, and in each case, the TAR is about one third less than the nominal capacity. The five minute and 60 minute results (See Appendix A, Table A3) show a decrease in capacity with operating time. This is probably because the reduction in capacity due to declining indoor temperature is greater than the increase incapacity due to declining outdoor temperature.

Table 8. Tons at the register after 30 minutes

\begin{tabular}{|l|c|c|c|}
\hline Site and test conditions & Total & Sensible & $\begin{array}{l}\text { Nominal Capacity from } \\
\text { outdoor unit nameplate }\end{array}$ \\
\hline Sacramento, as found & - & 1.2 & 2 \\
\hline $\begin{array}{l}\text { Sacramento, as found, } \\
\text { ENERGYSTAR Equipment }\end{array}$ & 1.7 & 1.3 & 2 \\
\hline $\begin{array}{l}\text { Sacramento, Leaks added, } \\
\text { ENERGYSTAR Equipment }\end{array}$ & 1.3 & 1.0 & 2 \\
\hline Cedar Park, as found & 2.0 & 1.3 & 3 \\
\hline $\begin{array}{l}\text { Cedar Park, as found, } \\
\text { ENERGYSTAR Equipment }\end{array}$ & 2.2 & 1.4 & 3 \\
\hline $\begin{array}{l}\text { Cedar Park, Leaks added, } \\
\text { ENERGYSTAR Equipment }\end{array}$ & 2.1 & 1.4 & 3 \\
\hline
\end{tabular}

\section{Air Conditioner Capacity}

Air conditioner capacity is a useful way of concentrating on the effect of low evaporator airflow or incorrect refrigerant charge by reducing the effects of leaks in the duct system. However, the impact of return leaks is included here because hot and humid air entering the return leaks (rather than the cooler and drier air from inside) changes the entering air conditions for the coil and therefore its capacity. This evaluation suffers the same sensor response limitations during the initial transient at the start of a cycle as TAR. Table 9 summarizes the 30 minute system capacities (The 5 minute and 60 minute data are shown in Appendix A, Table A4). These results show that the capacity at the coil is closer to the nominal capacity than the TAR discussed above because duct losses are not included. This effect of duct losses is shown by the reduction in capacity when leaks were added. The total capacity for Sacramento before the EnergyStar equipment was installed is not shown in Table 9 due to problems with the relative humidity measurements. 
Table 9. Capacity at the indoor coil after 30 minutes $(\mathrm{kW})$

\begin{tabular}{|l|c|c|c|}
\hline Site and test conditions & Total & Sensible & $\begin{array}{c}\text { Nominal Capacity from outdoor } \\
\text { unit nameplate }\end{array}$ \\
\hline Sacramento, as found & - & 5 & 7 \\
\hline $\begin{array}{l}\text { Sacramento, as found, } \\
\text { ENERGYSTAR Equipment }\end{array}$ & 6.9 & 5.4 & 7 \\
\hline $\begin{array}{l}\text { Sacramento, Leaks added, } \\
\text { ENERGYSTAR Equipment }\end{array}$ & 5.6 & 4.7 & 7 \\
\hline Cedar Park, as found & 9.5 & 6.9 & 10.5 \\
\hline $\begin{array}{l}\text { Cedar Park, as found, } \\
\text { ENERGYSTAR Equipment }\end{array}$ & 9.9 & 7.2 & 10.5 \\
\hline $\begin{array}{l}\text { Cedar Park, Leaks added, } \\
\text { ENERGYSTAR Equipment }\end{array}$ & 9.3 & 6.7 & 10.5 \\
\hline
\end{tabular}

\section{Comparing Measured and Rated Air Conditioner Capacity}

Comparisons of measured and rated air conditioner capacity are summarized in Table 10. For each site, the ACCA Manual J (1986) sensible load was calculated using the measured house dimensions and construction details. This was compared to data from the manufacturer (nameplate capacity), from the ARI (1999) ratings and the measured sensible TAR. The measured TAR were the quasi-steady-state values obtained after the equipment had been operating for 30 minutes so as not to include transient effects that are not part of the other ratings. These results show that the nameplate capacities far exceed the requirements of the Manual $J$ calculations indicating potential oversizing. The ARI and measured Maximum Sensible Capacity ratings diminish the oversizing effect but still reinforce the overrating in the nameplate capacities. The measured TAR is closer to the Manual J estimates and at Cedar Park the TAR is less than the Manual $J$ load estimate. These results illustrate the impact of the system performance in converting from what is purchased by the homeowner or contractor (nameplate capacity) and is actually delivered to the conditioned space (TAR). Sacramento has a TAR that is almost the same as the Maximum Sensible Capacity of the equipment. This is an unusual result, however, and the other sites examined for the companion study (Walker et al. (1999)) have considerable lower TAR than this maximum. Overall, the results shown in Table 10 illustrate that nameplate capacity is a poor way of evaluating the capacity of the equipment (compared to Maximum Sensible Capacity) and the system as a whole (TAR). In addition, the apparently gross oversizing of nameplate capacity compared to Manual $J$ is offset by lower actual equipment performance and thermal distribution system losses.

\begin{tabular}{|c|c|c|c|c|c|}
\hline \multicolumn{7}{|c|}{ Table 10. System capacity comparisons } \\
\hline Site & $\begin{array}{c}\text { Manual J } \\
\text { Sensible Load } \\
\text { [Tons] }\end{array}$ & $\begin{array}{c}\text { Nameplate } \\
\text { Capacity } \\
\text { [Tons] }\end{array}$ & $\begin{array}{c}\text { ARI } \\
\text { Capacity } \\
\text { [Tons] }\end{array}$ & $\begin{array}{c}\text { Maximum } \\
\text { Sensible } \\
\text { Capacity } \\
\text { [Tons] }\end{array}$ & $\begin{array}{c}\text { Tons at the } \\
\text { Register } \\
\text { [Tons] }\end{array}$ \\
\hline Sacramento & 1.02 & 2 & 1.9 & 1.56 & 1.5 \\
\hline Cedar Park & 2.28 & 3 & 2.9 & 2.34 & 1.8 \\
\hline
\end{tabular}

${ }^{1}$ What the capacity should be assuming no duct leakage, $400 \mathrm{cfm} / \mathrm{ton}$ airflow, perfect refrigerant charge, no additional safety factor.

\section{Air conditioner Coefficient of Performance (COP)}

Air conditioner COP is a measure of efficiency of an air conditioner, and it is typically around 2-3 for a residential unit. Unlike the COPs presented by the manufacturer, the COPs reported here include the energy (and heat 
generation) of the air handler fan. Table 11 summarizes the measured COPs, system power consumption and the fraction of this power drawn by the air handler fan after 30 minutes. System power consumption includes the compressir, outdoor fan and air handler fan. As with the indoor coil capacity discussed earlier, the addition of leaks tends to reduce the COP. The measured sensible COP for the ENERGYSTAR equipment is about 25\% higher then the

* original equipment in Sacramento and about the same in Cedar Park. In all the tests the fan power consumption was a significant fraction of the total $(15 \%-30 \%)$. This indicates that there are substantial performance gains to be had by improving the distribution fan efficiency and reducing system pressure drop. The five and sixty minute results are given in Appendix A, Tables A5 and A6.

\begin{tabular}{|l|c|c|c|c|}
\hline \multicolumn{5}{|c|}{ Table 11. Equipment Coefficient of Performance (COP), Power Consumption and } \\
fraction of power consumption due to fan, after 30 minutes \\
\hline Site and test conditions & $\begin{array}{c}\text { Sensible } \\
\text { COP }\end{array}$ & $\begin{array}{c}\text { Total } \\
\text { COP }^{1}\end{array}$ & $\begin{array}{c}\text { System Power } \\
\text { Consumption } \\
(\mathrm{kW})\end{array}$ & $\begin{array}{c}\text { Air Handler Fan power } \\
\text { as fraction of total (\%) }\end{array}$ \\
\hline Sacramento, as found & 1.8 & - & 2.9 & 20 \\
\hline $\begin{array}{l}\text { Sacramento, as found, } \\
\text { ENERGYSTAR Equipment }\end{array}$ & 2.4 & 3.0 & 2.4 & $30^{2}$ \\
\hline $\begin{array}{l}\text { Sacramento, Leaks added, } \\
\text { ENERGYSTAR Equipment }\end{array}$ & 2.2 & 2.7 & 2.1 & 30 \\
\hline Cedar Park, as found & 1.9 & 2.6 & 3.7 & 20 \\
\hline $\begin{array}{l}\text { Cedar Park, as found, } \\
\text { ENERGYSTAR Equipment }\end{array}$ & 1.9 & 2.7 & 3.7 & 15 \\
\hline $\begin{array}{l}\text { Cedar Park, Leaks added, } \\
\text { ENERGYSTAR Equipment }\end{array}$ & 1.7 & 2.4 & 3.9 & 20 \\
\hline
\end{tabular}

1- Not shown for Sacramento before the EnergyStar equipment was installed due to problems with the RH measurements.

2 - Large variation indicating a variable speed compressor.

\section{System Coefficient of Performance (COP)}

System COP is the most inclusive performance measure: it is a simple ratio of the cooling energy delivered to the conditioned space (TAR) divided by the power consumption of the air conditioner and fan. System COP combines the changes in the air conditioner capacity as well as any losses/gains in the distribution system. Table 12 shows the small increases in system COP due to installing ENERGYSTAR Equipment and the small reduction in system COP due to adding leaks. Appendix A, Table A7 gives the additional test results for five and sixty minute data. 
Table 12. Total System Coefficient of Performance (COP) after 30 minutes

\begin{tabular}{|l|c|c|}
\hline Site and test conditions & Sensible & Total $^{1}$ \\
\hline Sacramento, as found & 1.5 & - \\
\hline $\begin{array}{l}\text { Sacramento, as found, } \\
\text { ENERGYSTAR Equipment }\end{array}$ & 2.0 & 2.5 \\
\hline $\begin{array}{l}\text { Sacramento, Leaks added, } \\
\text { ENERGYSTAR Equipment }\end{array}$ & 1.7 & 2.1 \\
\hline Cedar Park, as found & 1.2 & 1.9 \\
\hline $\begin{array}{l}\text { Cedar Park, as found, } \\
\text { ENERGYSTAR Equipment }\end{array}$ & 1.4 & 2.1 \\
\hline $\begin{array}{l}\text { Cedar Park, Leaks added, } \\
\text { ENERGYSTAR Equipment }\end{array}$ & 1.3 & 1.9 \\
\hline
\end{tabular}

1- Not shown for Sacramento before the EnergyStar equipment was installed due to problems with the RH measurements.

\section{Delivery Effectiveness (DE)}

Delivery Effectiveness is the total capacity at the registers divided by the capacity at the air handler and does not include any regain of losses or the energy and comfort implications of duct leakage to inside. DE separates duct only effects from the other system performance parameters included in TAR and COP (e.g., it does not include refrigerant charge effects). Table 13 shows DE for both sensible and total capacity after the system has been operating for 30 minutes. After 30 minutes, the system is operating in quasi-steady-state and the DE will not be significantly affected by any transient thermal mass effects of the duct system and cooling equipment. Additional results (Shown in Appendix A, Table A8) indicate that DE can be higher after five minutes of operation than the 30 minute values in Table 13. This is mostly because the whole duct system has not cooled down from its initial high temperature in the attic. Because the duct temperatures are higher, the conduction losses are lower, and this is reflected in a higher measured DE. For Sacramento, the results of sealing the duct system. are much more apparent when looking at delivery effectiveness rather than the TAR given in Table 8.

Table 13. Delivery Effectiveness [\%] after 30 minutes

\begin{tabular}{|l|c|c|}
\hline Site and test conditions & Sensible & Total \\
\hline Sacramento, as found & 0.85 & 0.89 \\
\hline $\begin{array}{l}\text { Sacramento, as found, } \\
\text { ENERGYSTAR Equipment }\end{array}$ & 83 & 85 \\
\hline $\begin{array}{l}\text { Sacramento, Leaks added, } \\
\text { ENERGYSTAR Equipment }\end{array}$ & 77 & 79 \\
\hline Cedar Park, as found & 0.67 & 0.75 \\
\hline $\begin{array}{l}\text { Cedar Park, as found, } \\
\text { ENERGYSTAR Equipment }\end{array}$ & 78 & Insufficient data \\
\hline $\begin{array}{l}\text { Cedar Park, Leaks added, } \\
\text { ENERGYSTAR Equipment }\end{array}$ & 75 & 80 \\
\hline
\end{tabular}

\section{Field Measurement Summary}

- Improving ducts by reducing leakage can lead to significant energy efficiency gains in addition to increasing the TAR, and increases comfort by reducing pulldown time.

- Systems can have good efficiency, but not give sufficient comfort to occupants due to poor room-by-room distribution.

- Using higher SEER units indicated larger sensible than total energy savings. Sensible performance increased by $25 \%$ at one site and less than $5 \%$ at the other. The latent performance was harder to interpret due to 
uncertainties in Relative Humidity measurements.

- Installed capacity (TAR) is considerably less than nameplate and ARI ratings. In addition, nameplate and ARI ratings exceed ACCA Manual J load estimates.

- Thermal distribution system losses and poor equipment installation combine to reduce nameplate and ARI capacities toward ACCA Manual J load estimates.

- The total duct leakage for the test houses was less than in previous studies and was between the default value and minimum requirement for duct leakage credit in T24 (22\% and 6\% respectively). Because an objective of this study was to investigate the interactions between duct losses and equipment operation, leakage was added to the duct systems to simulate more typically leaky systems.

- Boot and cabinet leakage contributes $25 \%$ to $50 \%$ of the total duct leakage at operating conditions and about three quarters of the fixed pressure test leakage.

- The duct leaks added an average of $0.2 \mathrm{ACH}$ to the ventilation rates of the tested houses.

\section{Modeling Improved Comfort with REGCAP}

Some of the details of the simulation model (called REGCAP) are given in previous work by Walker et al. (1998a and 1998b) and Walker et al. (1999). A flowchart for the simulation program is shown in Appendix B. The thermal and ventilation parts of REGCAP were adapted from existing models that were specifically developed to examine attic performance. These models of ventilation and heat transfer, excluding the ducts, have been verified with extensive field measurements (Walker (1993)). The airflow modeling for REGCAP combines the existing ventilation models for the house and attic with duct register and leakage flows using mass balance of air flowing in and out of the house, attic and duct system. The thermal modeling uses a lumped heat capacity approach so that transient effects are included. The ventilation and thermal models interact because the house and attic ventilation rates depend on house and attic air temperatures, airflow through duct leaks, and the energy transferred by the duct system depends on the attic and house temperatures. Recent model developments made during this study included additional airflow paths through duct leaks when the system is not operating and a moisture balance for use in latent load and equipment capacity calculations. A simple thermostat model and the ability to make calculations at small timesteps allows the model to be used for examining cyclic effects. REGCAP is a single-zone model and does not perform energy or airflow calculations for every room in the house so the simulation results only apply to "whole house" values and cannot be used to estimate room-by-room comfort estimates. The reason for this single zone approach is that the information required to perform multi-zone calculations is generally unknown and is difficult to determine even for case studies like those performed in the field measurement section of this study. For example, characterizing all the potential airflow paths through the envelope of the house and between every room of the house is essentially impossible.

The comfort delivered by each system was evaluated by simulating pulldown time and TAR at various times during the pulldown. In the same way as the measured data, the pulldown was simulated by having the air-conditioner off from midnight to 3:00 p.m. Then at 3:00 p.m., the air conditioner was turned on. The simulation model was used to calculate the system performance in one minute time steps for a whole day (including times when the system is off). In the previous work (Walker et al. (1998a and 1998b), the timesteps had been set to 15 minutes, but this was found to be too coarse a timestep for capturing all the transient behavior of the systems.

The following list gives the key model input parameters:

Envelope leakage. For both house and attic.

Envelope thermal parameters. Insulation and construction details for house and attic.

Weather. Outside air temperature and relative humidity, wind speed, wind direction and solar loads (total and diffuse).

Refrigerant Charge. The refrigerant change was set to three levels representative of those measured in field testing.

Airflow across coil. The airflow was set to two levels representative of those measured in field testing.

Duct Leakage. Duct leakage was set to levels representing field test results, CEC ACM compliant and ideal (no leakage) ducts.

Air handler and duct location. This was either the attic (typical of new construction) or inside the conditioned space.

Equipment Capacity. The capacity was calculated using an equipment model developed by John Proctor. 
The equipment model used to predict the capacity of the air conditioners for the REGCAP simulation is an empirical model developed by John Proctor. This model is the only available model that accounts for refrigerant charge level and is sufficiently general for use in this project. This model has been used in several research projects (Proctor (1997), (1998a) and (1998b)) and is continually updated as new data are collected. Currently, the portion of the model that accounts for deviation from recommended refrigerant charge is taken directly from Rodriguez et al. (1995) and the rest of the model is from Proctor Engineering Group fieldwork in about one hundred houses. The equipment model requires the following inputs: nominal (nameplate) capacity, ARI capacity, airflow, outside temperature, indoor (return plenum) enthalpy, refrigerant charge level, and expansion valve type (capillary tube/orifice or TXV (thermostatic expansion valve)). The equipment model predicts sensible capacity and, with the assumption of a sensible heat ratio for the unit, latent and/or total capacity can also be predicted. A comparison to the measured capacities at the two houses in this study (plus another four from the companion study) indicate that the model overpredicts capacity by about $10 \%$. There is no obvious reason for this consistent deviation from Proctor's data, but a possible reason is that most of the Proctor's verification of the model occurred in very dry climates, rather than the more humid weather that we encountered during the field testing and the simple assumption about latent load requires refining.

\section{REGCAP Simulation Evaluation}

An essential part of simulation design and use was verifying that the simulation makes accurate predictions. In this case, we were interested in predicting two parameters: tons at the register (delivered capacity) and pulldown time (time to cool down the house). REGCAP was validated by comparing predicted temperatures to measured temperatures. Given the same temperatures, other variables used to determine energy flows (e.g., register flowrates) and comfort parameters (e.g., pulldown times) are the same for both modeled and measured data. For this purpose, we examined the temperatures of four air nodes: attic, house, supply duct and return duct.

Over 100 days of measured data at 5 sites were used to evaluate REGCAP ( 4 in California and 1 in Texas). Overall there was very good agreement between measured house and attic temperatures and REGCAP predictions. There was also good agreement between the duct air temperatures when the air handler fan was on, but not very good agreement when the air handler was off. In order to illustrate these and other strengths and weaknesses of REGCAP, the predicted and measured temperatures are shown for one site and each of the four (house, attic, return and supply) modeled temperatures will be discussed individually. There was no attempt to show data that were either particularly favoring or condemning of REGCAP. The following illustrations are included to demonstrate both the strengths and the weaknesses of the model. The generalized discussion applies to all the comparisons between measured and modeled data. 


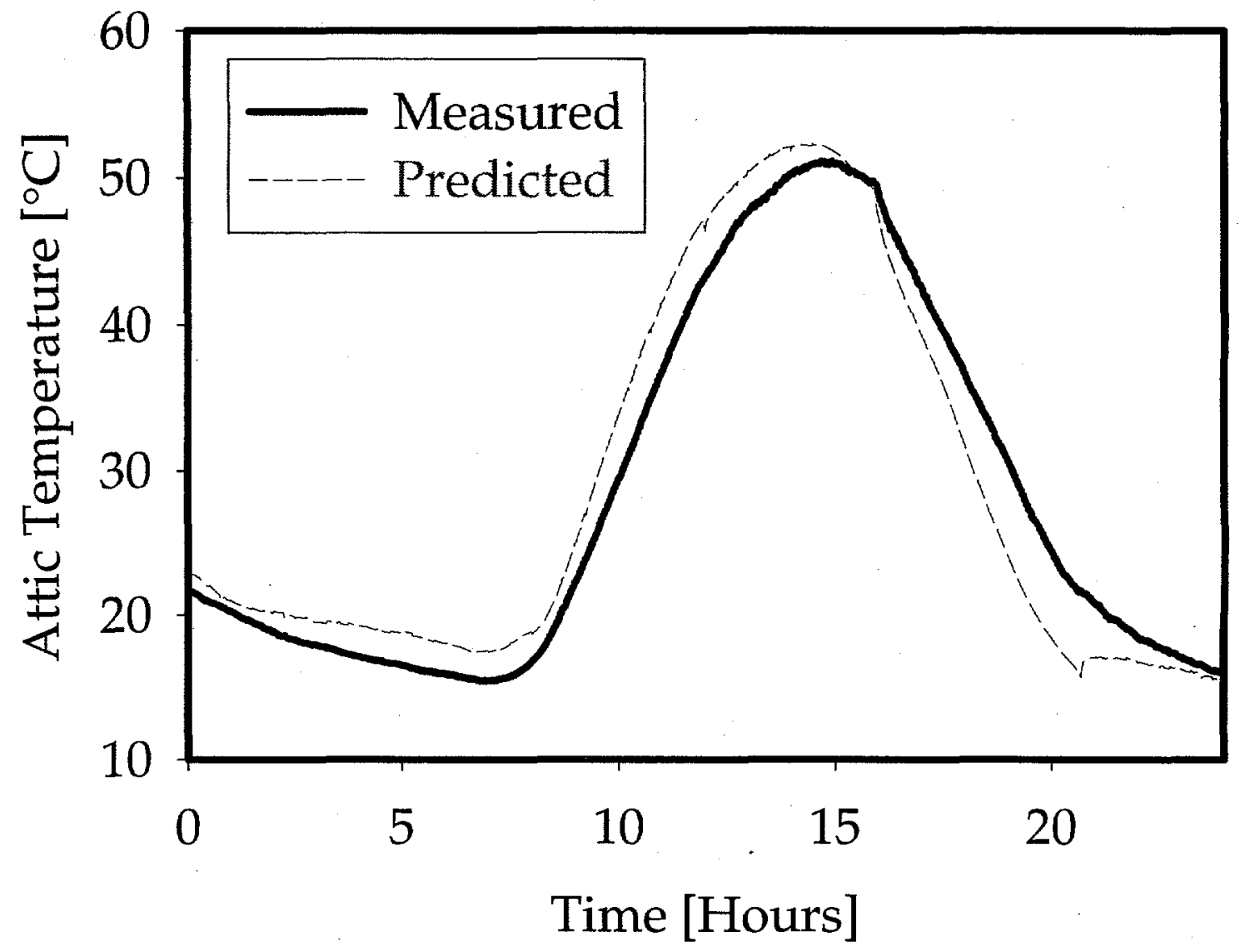

Figure 1: REGCAP Predicted and Measured Attic Temperatures for the Sacramento test house. August 11, 1998

\section{Attic Temperature}

Figure 1 shows good agreement between the REGCAP predicted and the measured attic temperature over the whole day. The agreement is excellent for the first half of the day and then the predicted temperature drops slightly below the measured temperature later in the day. The average absolute difference in temperatures over the day was $2.4^{\circ} \mathrm{C}$ $\left(4.3^{\circ} \mathrm{F}\right)$. There are several hypotheses that explain this small discrepancy. The most plausible is a problem with the measured solar radiation input data (the dip in the data when the sun comes up is an indication of this). Another possibility is that the ducts are too strongly coupled with the house so that when the air conditioner comes on the duct leakage cools the attic more in the REGCAP predictions than in the measured case. Another possible problem is that the radiative transfer involving the attic endwalls and the combined mass of wood in the attic was neglected. 


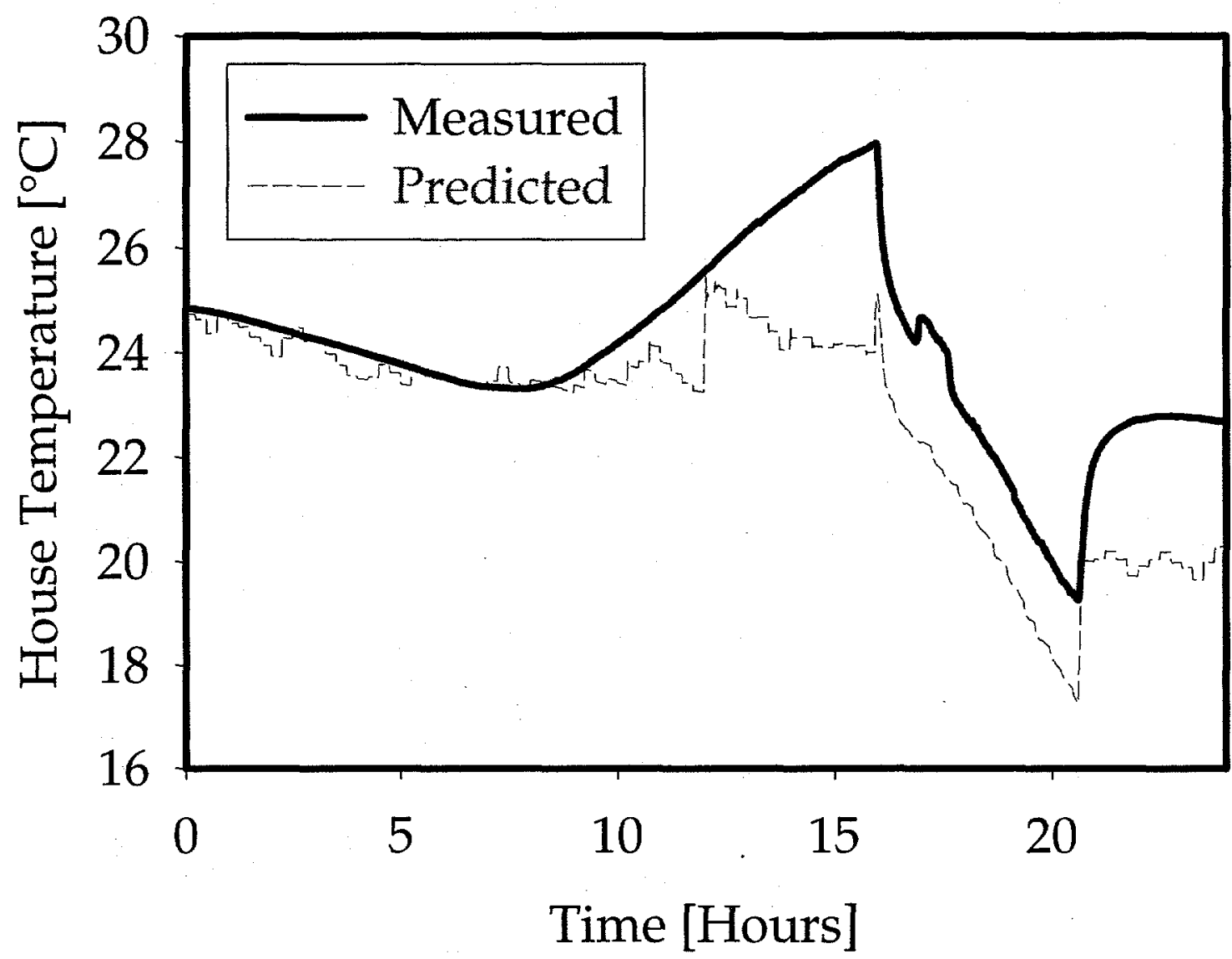

Figure 2: REGCAP Predicted and Measured House Air Temperatures for the Sacramento test house. August 11, 1998

\section{House Temperature}

The comparison of house temperatures for the Sacramento tests house is shown in Figure 2. The measured temperatures are taken at the location of the thermostat that controls the air conditioner. The house air temperatures are predicted better than the attic air temperatures. The average absolute difference between the REGCAP predicted and the measured values is $0.4^{\circ} \mathrm{C}\left(0.7^{\circ} \mathrm{F}\right)$. The predicted temperatures are less smooth than the measured temperatures because the modeled house air responds very quickly to changes in weather conditions. Each discontinuity in the predicted temperatures is a change in input weather data (for which we have 15 minute averages only). The rapid reaction of indoor temperatures to the change in weather conditions is probably because of insufficient coupling between the house air and the house mass. There are two most likely causes of this problem: the first is that the interior surface convection heat transfer coefficient is biased towards natural, rather than forced convection. This is possibly a poor assumption when the air handler is on. This is a good example of where reducing an input requirement (i.e. not requiring average air velocity in the house to be known) may lead to a less accurate predicted result. The second is that the surface area active in heat exchange between the thermal mass of the house and house air is too small in the model. Future work will further investigate the convection heat transfer 
coefficient thermal mass issue.

Examination of the weather data collected on the day of test indicates very strong winds from about 11 am until 6 p.m. This failure of REGCAP to deal with extreme conditions and is probably the cause of the wide temperature swings evident in the measured data. The REGCAP prediction has a single spike in the temperature when the air conditioner comes on. This is an artifact of the ducts pushing hot air into the house that doesn't seem to be evident in the measured data (which was collected every 10 seconds, a finer resolution than the minute long timestep used by REGCAP). Despite these discrepancies, predicted house temperatures reflect the overall shape of the temperature curve in each house. An improved house load model will be developed and used in the future.

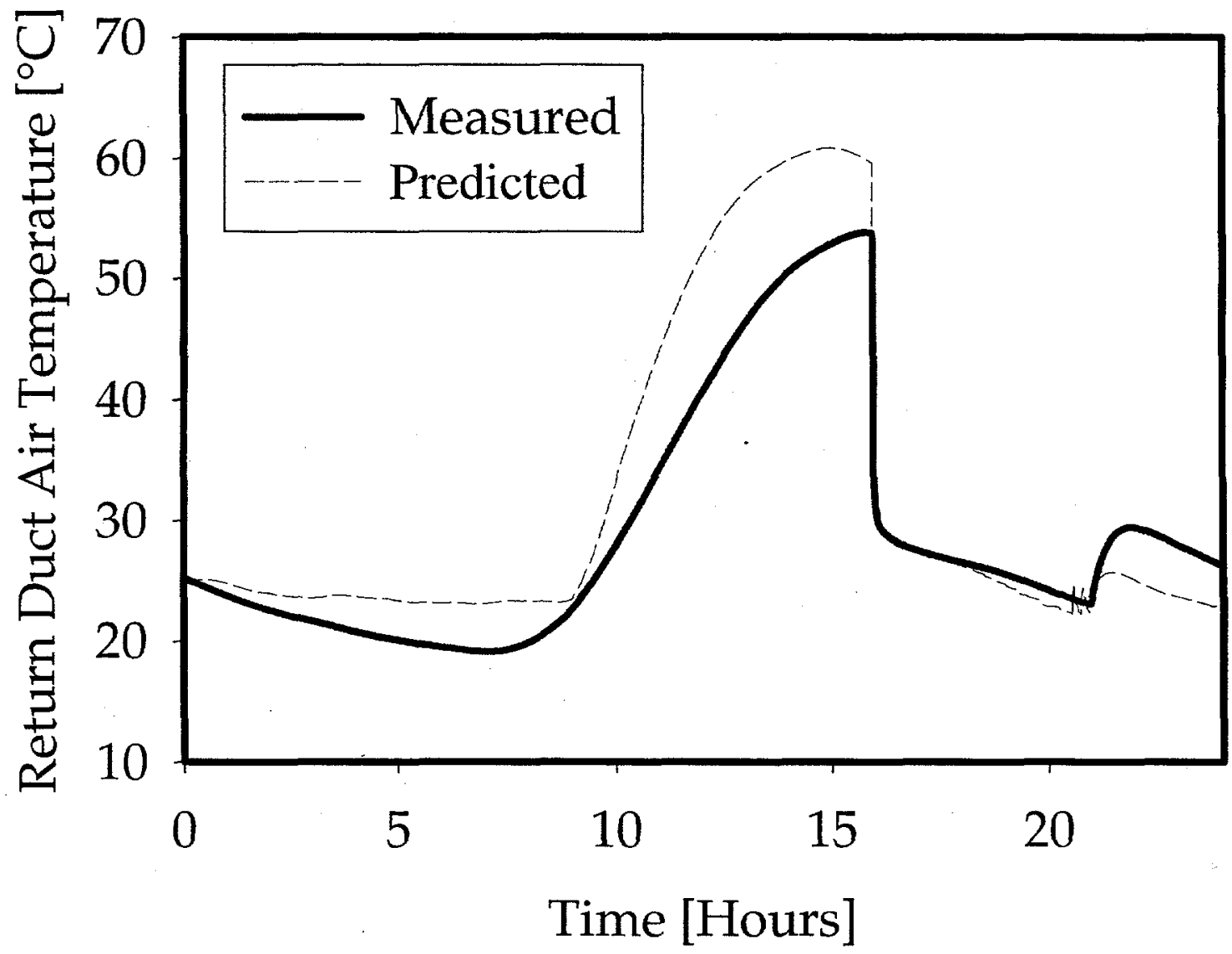

Figure 3: REGCAP Predicted and Measured Return Duct Air Temperatures for the Sacramento test house. August 11, 1998

\section{Return Duct Air Temperature}

The agreement between measured and predicted return duct temperatures shown in Figure 3 is quite good when the air conditioner is on (absolute difference of only $0.3^{\circ} \mathrm{C}$ ). Overall, REGCAP does an adequate job of predicting the 
return duct air temperature when the air handler fan is on. When the air handler is off, the predicted duct air temperature is much hotter than the measured temperature (absolute difference of $5.1^{\circ} \mathrm{C}$ ). The REGCAP predicted return duct temperature with the system off is close to the attic air temperature, which is expected because the ducts are in the attic, but the measured results have lower return temperatures. The most likely reasons for this difference are factors that we have not included in REGCAP (because the input data required to perform the calculations is difficult to determine) or measurement problems. The two most likely sources of uncertainty are:

1. Stratification of air inside the duct such that the measured air temperature is near a cool point.

2. Additional indoor airflow through the system due to room-to-room pressure differences caused by air infiltration flows.

The spatial temperature variation point is one that always occurs with simplified modeling and measurement when assumptions are made about air being well mixed at the measurement location. Without making more measurements at more locations we cannot tell if this is a big problem or not. In future work we will need to examine this issue in more detail. We need to be careful in not tweaking REGCAP to match these measured results in case the measurements are an anomaly due to large temperature variations.

When the system is off REGCAP does include air flows from the house into the duct due to ventilation (caused by pressure differences due to temperature, wind effects and mechanical ventilation). The measured results could be better matched by REGCAP if these airflows were increased. It is possible that the pressure differences between rooms in the house may cause additional flows that REGCAP does not account for. However, to include these flows would require detailed multizone modeling for which the inputs (airflow resistance between rooms, including the flow resistance of each individual duct) are not known. These inputs are very difficult to measure for an individual house and it is not practical to require them as model input. One possibility is to make up some values and perform parametric modeling, however this would not improve the match between measured and modeled data that we are discussing here. In addition, given the uncertainty in measurement discussed above (due to spatial temperature variations) it is not possible to justify this additional modeling effort.

The ducts in contact with the floor could be accounted for by making additional observations of the ducts as installed in the test houses and then adding a conduction path to the house for the attic ducts. This is has been added as an option for REGCAP. However, it is difficult to estimate the contact area and insulation value for ducts lying on the attic floor.

Although the above discussion shows that there may be some complex heat transfer issues not included in REGCAP, it should be noted that the large discrepancies only apply when the system is off. They would only affect the initial transient performance of REGCAP and would not significantly change any of the predictions during system operation. 


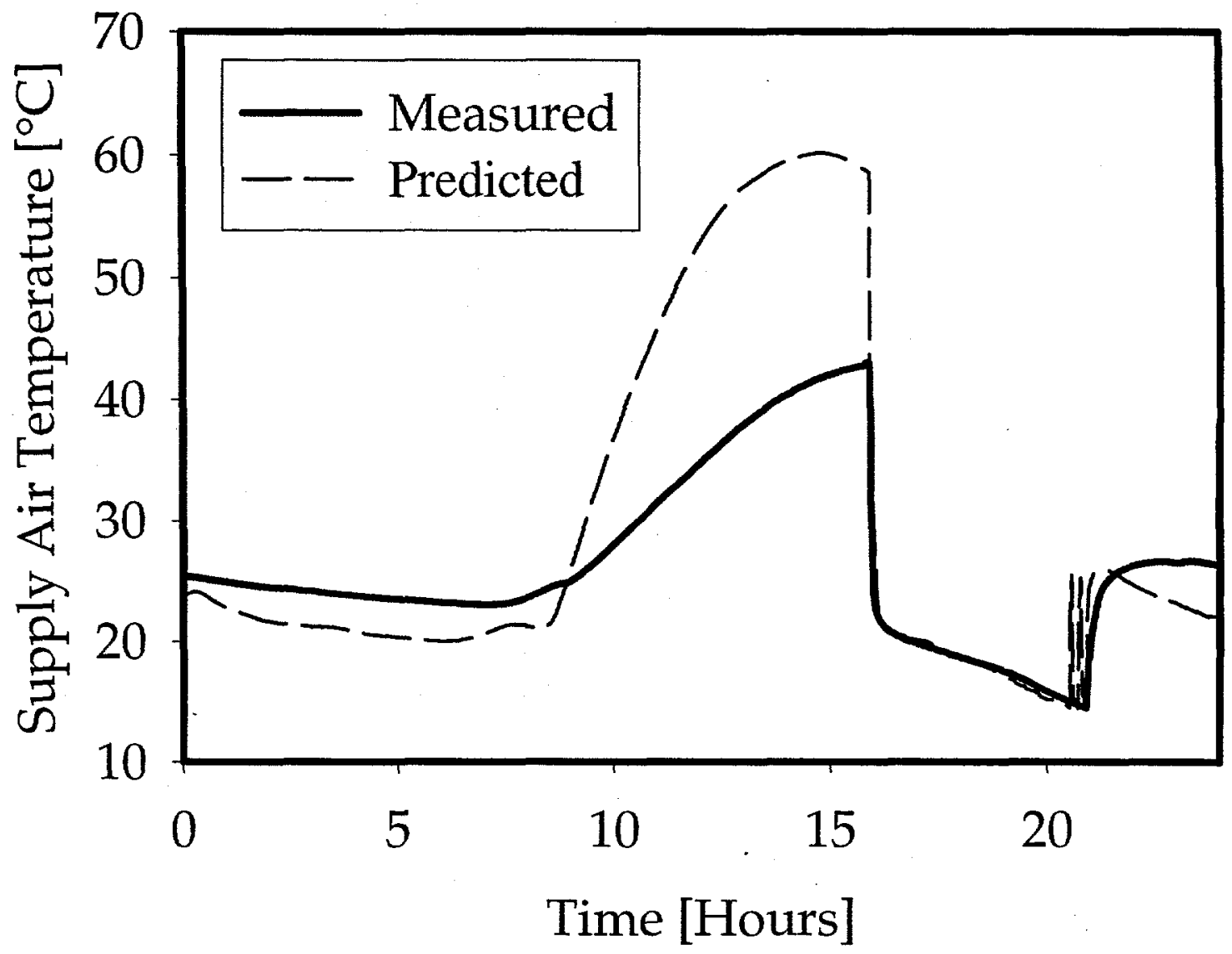

Figure 4: REGCAP Predicted and Measured Supply Duct Air Temperatures for the Sacramento test house. August 11, 1998

\section{Supply Duct Air Temperature}

Like the return duct air temperature, the supply duct air temperatures show good agreement when the air handler fan is on, but poor agreement when the air handler fan is off. When the air handler is off, the REGCAP predicted supply duct temperature is very strongly influenced by the attic temperature and radiation exchange with the interior attic surfaces. The agreement is not very good for the supply duct air temperatures when the air handler is off for the same reasons as for the return ducts.

The lack of air-handler off agreement for the duct temperatures is not particularly significant for the objectives of this study: predicting the pulldown time and the tons at the register. The only temperatures that are directly needed for these calculations are the house air temperature and the supply duct air temperature when the air conditioning fan is on. For this reason, REGCAP is well suited to calculating the performance parameters that are the focus of this project. 


\section{REGCAP Simulation Results}

The improved model was used to reexamine the pulldown simulations performed previously by Walker et al. (1998 and 1998b). In the simulations, eight different thermal distribution systems are used in the same house for the same weather conditions. The results shown here use a day of TMY data for Sacramento, CA (NCDC (1980)) for which the peak temperatures most closely matched the ASHRAE (1997) 1\% design values. In the previous work the simulations were used to show how pulldown time changed with duct system performance, different weather conditions (a typical design day and the maximum load day) and with system capacity.

Table 14 lists the simulation cases that were examined here. The BASE case is typical of new construction in California. The POOR system represents what is often found at the worst end of the spectrum in existing homes. The BEST system is what could reasonably be installed in new California houses using existing technologies and careful duct and equipment installation to manufacturers' specifications. The BEST RESIZED system looks at the possibility of reducing the equipment capacity while using the best duct system. The INTERIOR system examines the gains to be had if duct systems are moved out of the attic and into conditioned space. The INTERIOR RESIZED system examines the system performance when reduced capacity equipment is used together with interior ducts. Lastly, the IDEAL system is an interior duct system that has been installed as well as possible. The IDEAL OVERSIZED simulations were included to examine the difference in pulldown if the IDEAL system were sized using current sizing methods (i.e., 4 tons).

The simulations were able to show several key results:

- A good duct system (with the correct refrigerant charge, little or no leakage and the right flow across the coil) allowed the capacity of the equipment to be reduced by about one third: from four tons to three tons nameplate capacity.

- If system nameplate capacity is unchanged, either improving duct systems (to have little leakage) and correctly installing the equipment, or moving the ducts inside the conditioned space results in significant pulldown performance improvements. In these cases pulldown times were reduced by more than an hour and initial tons at the register were approximately doubled.

- The model results also showed the wide range of pulldown times for different duct systems.

The large range of pulldown results are illustrated in Figure 5, with each simulation starting at the same time. The better systems were able to pulldown the house in a reasonably short time (under three hours) but the poor systems took over five hours. The longer pulldown times mean that the house would not be as comfortable for occupants returning in the afternoon. For example, the house with the POOR system is still not pulled down at 8:00 p.m. For the occupants this may be unacceptable.

Note that pulldown tests focus on capacity at the registers and how this changes the pulldown time. With good distribution systems and reduced equipment capacity it may be better to not turn the system off during the day (set-up followed by afternoon pulldown) and allow the system to cycle. In addition, the continuous operation (non-set-up) will be of more use for providing humidity control in humid environments. 


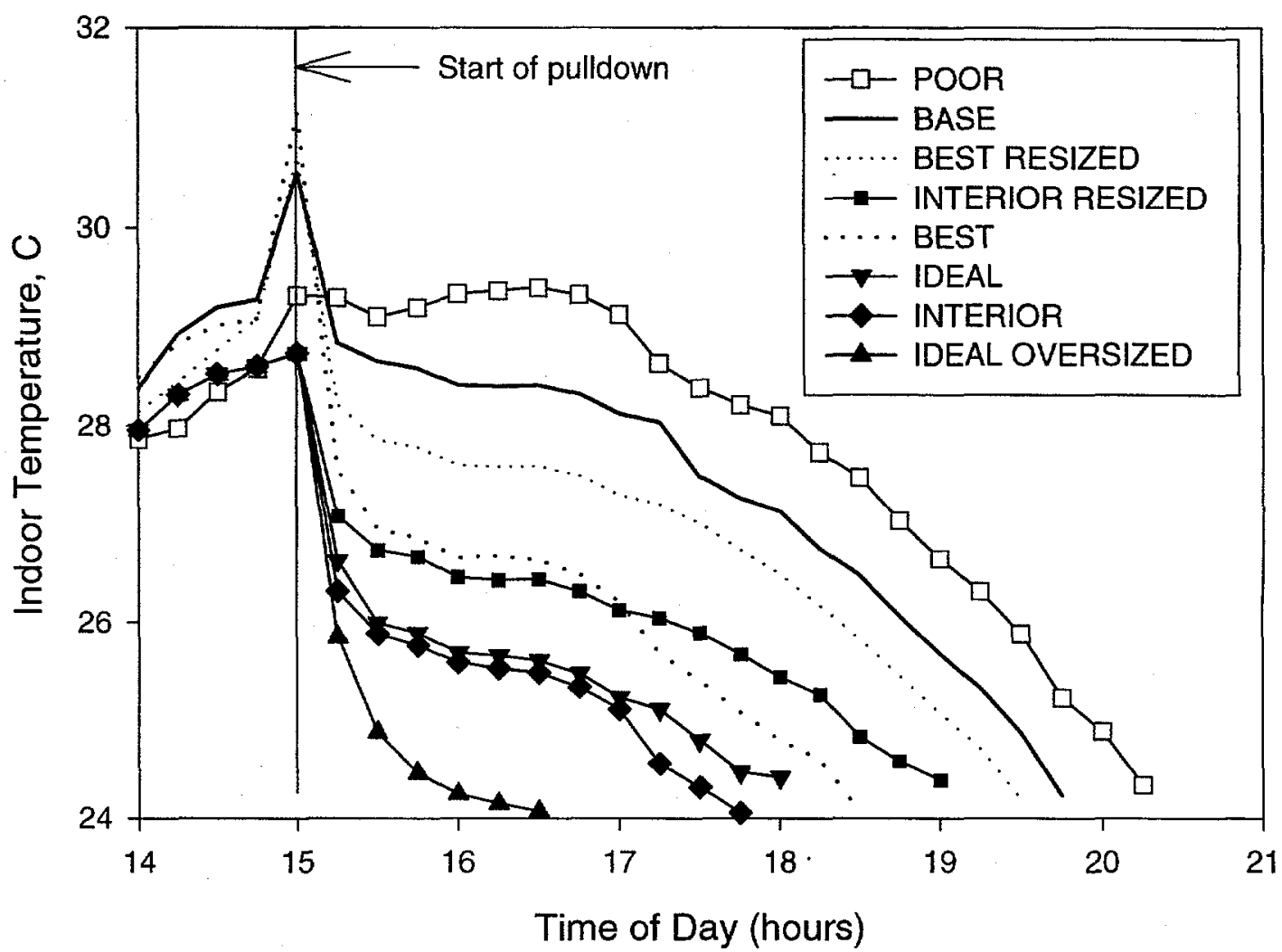

Figure 5. REGCAP Simulations of pulldowns from 3:00 p.m. on a Sacramento design day.

Table 15 compares the results of the calculated TAR based on the simulations. Note that for these calculations the systems have been running for almost two hours and are at quasi-steady-state and do not show the transient capacity reductions at the start of the pulldown. This was done so that we are not unfairly comparing the nameplate capacity to the transient system performance. In other words, we are being as generous as possible in our comparisons by reporting close to the highest system capacities. All but the POOR ducts are better than the BASE case in terms of delivered TAR and also TAR as a fraction of the nameplate capacity of the equipment. All of the resized systems have TAR closer to their nominal capacity than for the BASE case. However in all cases (even the ideal situation with correct system charge and airflow and minimal duct losses) the equipment capacities are much less than the nameplate rating on the equipment that a home owner, builder or HVAC equipment installer has paid for.

These simulation results reinforce the following conclusions from the previous studies:

- Improved ducts and system installation can allow the use of a smaller capacity air conditioner (almost one ton less in the cases studied here, and at least one ton in more demanding situations) without any comfort penalty in terms of pulldown time. As part of the companion study, Walker et al. (1999) also showed that the smaller capacity air conditioners could also have large energy savings (roughly halving energy consumption required for pulldown). 
- If system nameplate capacity is unchanged, either improving duct systems and correctly installing the equipment, or moving the ducts inside results in significant pulldown time reductions.

- Systems do not provide their nameplate capacity at design conditions, when system capacity is most critical.

\begin{tabular}{|l|c|c|c|c|c|}
\hline \multicolumn{7}{|l|}{ Table 14. List of REGCAP Simulation Cases } \\
\hline & $\begin{array}{c}\text { System } \\
\text { Charge }\end{array}$ & $\begin{array}{c}\text { Air Handler } \\
\text { Flow }\end{array}$ & $\begin{array}{c}\text { Duct } \\
\text { Leakage } \\
\text { Fraction }\end{array}$ & $\begin{array}{c}\text { Duct and } \\
\text { equipment } \\
\text { Location }\end{array}$ & $\begin{array}{c}\text { Nameplate } \\
\text { Rated } \\
\text { Capacity }\end{array}$ \\
\hline & {$[\%]$} & {$[$ CFM/Ton] } & {$[\%]$} & & [Tons] \\
\hline BASE & 85 & 345 & 11 & Attic & 4 \\
\hline POOR & 70 & 345 & 30 & Attic & 4 \\
\hline BEST & 100 & 400 & 3 & Attic & 4 \\
\hline BEST RESIZED & 100 & 400 & 3 & Attic & 3 \\
\hline INTERIOR & 85 & 345 & 0 & House & 4 \\
\hline INTERIOR RESIZED & 85 & 345 & 0 & House & 3 \\
\hline IDEAL & 100 & 400 & 0 & House & 3 \\
\hline IDEAL OVERSIZED & 100 & 400 & 0 & House & 4 \\
\hline
\end{tabular}

Table 15. REGCAP Delivered Capacity (TAR) Comparison (System on for 1.75 hours)

\begin{tabular}{|l|c|c|c|c|}
\hline & $\begin{array}{c}\text { Nameplate } \\
\text { Capacity }\end{array}$ & $\begin{array}{c}\text { Tons at the } \\
\text { Register } \\
\text { (TAR) }\end{array}$ & $\begin{array}{c}\text { Tons at the Register } \\
\text { Nameplate Capacity }\end{array}$ & $\begin{array}{c}\text { Ratio to } \\
\text { Base Case }\end{array}$ \\
\hline & {$[$ Tons] } & {$[$ Tons] } & {$[\%]$} & {$[\%]$} \\
\hline BASE & 4 & 1.66 & $42 \%$ & $100 \%$ \\
\hline POOR & 4 & 1.51 & $38 \%$ & $91 \%$ \\
\hline BEST & 4 & 2.21 & $55 \%$ & $133 \%$ \\
\hline BEST RESIZED & 3 & 1.66 & $55 \%$ & $133 \%$ \\
\hline INTERIOR & 4 & 1.84 & $46 \%$ & $\mathbf{1 1 0 \%}$ \\
\hline INTERIOR RESIZED & 3 & 1.36 & $45 \%$ & $109 \%$ \\
\hline IDEAL & 3 & 1.68 & $56 \%$ & $135 \%$ \\
\hline IDEAL OVERSIZED & 4 & 2.28 & $57 \%$ & $\mathbf{1 3 7 \%}$ \\
\hline
\end{tabular}

\section{Technology Transfer}

The following are duct system technology transfer issues that have been investigated as part of this study.

\section{Duct Cleaning effect on aerosol sealant (EPA).}

An issue that has been raised regarding the aerosol sealant is its resistance to duct cleaning. Ducts are cleaned in order to remove build-ups of dust that can lead to poor indoor air quality. Unlike sealants applied to the outside of ducts (e.g., duct tape), the aerosol sealant is applies from the inside and may be more sensitive to abrasion caused by duct cleaning efforts. In order to examine this effect, a sheet metal duct system was sealed with the aerosol sealant 
and then cleaned by professional duct cleaners. The duct cleaners were local HVAC contractors who cleaned the ducts as they would for a regular service call. No attempt was made to change the tasks they performed in order to make the duct cleaning more effective. The cleaning was about four years after the initial aerosol sealing. The system was cleaned four times in total.

The first contractor vacuumed duct system supply four times: supply system twice and return system once and both systems the same time once. For the first vacuuming, all of the registers were taped and furnace was isolated. An 8" diameter vacuum hose was connected to the supply plenum. The system was vacuumed for about 15 minutes. The pressure difference between the duct and the house (measured at the furthest part of the duct system from where the vacuum hose was connected) was $35 \mathrm{~Pa}$. The relatively low vacuum pressure was because the cardboard used to isolate the furnace was misplaced and resulted in a big leak. After this leak was fixed, the pressure difference between the duct and the house increased to $254 \mathrm{~Pa}$. The return was vacuumed separately. The two return registers were taped and the furnace was isolated. The return duct was also vacuumed for about 15 minutes. The pressure difference between the return duct and the house was $980 \mathrm{~Pa}$ falling to $540 \mathrm{~Pa}$ at the end of the vacuum cleaning. A duct leakage measurement was performed after the above cleaning procedures, and the supply and return leakage were unchanged - within $0.1 \mathrm{cfm} 25$ of the pre cleaning leakage (Before the system was cleaned the measured leakage was $6.2 \mathrm{cfm} 25$ supply and $9.3 \mathrm{cfm} 25 \mathrm{return}$.).

For the next cleaning an 8" diameter vacuum hose was connected to the furnace burner access panel. Only a rudimentary attempt was made to seal around this connection using a rag wrapped around the hose. All of the registers were simply covered with pieces of paper rather than being completely sealed. The pressure difference between the ducts and the house was about $220 \mathrm{~Pa}$ and stayed at the same level during the vacuuming process. After these two vacuumings, the duct leakage was measured to be $6.6 \mathrm{cfm} 25$ for the supply and $9.0 \mathrm{cfm} 25$ for the return. This result shows that the leakage was again unchanged (within the experimental uncertainty of $\pm 1 \mathrm{cfm}$ ) by the vacuuming process.

A second HVAC contractor then vacuumed the duct system with a combination of inserting a spinning brush into the ducts at the registers and brushing all the way to plenum if there was no damper to block it. This was a more severe test of the aerosol sealant because it might have been abraded by the brushes. The supply and return duct systems were isolated and each grille was removed before inserting the spinning brush and then the register was plugged with a piece of foam. The supply duct was depressurized to about $330 \mathrm{~Pa}$. After this brushing and vacuuming, the measured leakage was $7.9 \mathrm{cfm} 25$ for the supply and $9.8 \mathrm{cfm} 25$ for the return. This shows a small increase was possibly caused by a change in the leakage at the boot to wall seal where aerosol deposition was disturbed when the grille was removed. However this amount of extra leakage (less than $2 \mathrm{cfm}$ ) is not significant given the measurement uncertainty.

It should be noted that the vacuuming without the brush did not appear to remove much dust from the system. The combination of vacuuming and brushing was much more effective and included the removal of a paper cup and a half roll of duct tape.

The conclusions drawn from these tests is that duct cleaning of a system sealed using the aerosol sealant does not remove the sealant and there is a large variation between contractors of duct cleaning thoroughness. Further tests are required on more systems to determine if the sealant is as durable as these tests indicate.

\section{Health and Safety Assessment of Aerosol Sealant (EPA)}

As with any new industrial material, concern exists over the potential human health hazards related to exposure to the aerosol sealant. Potential health and safety issues regarding the duct seal material were evaluated and discussed by Buchanan (1999). That report examined the characteristics of the sealants individual components based on a review of the current literature. Buchanan indicated that there are three primary means by which exposure could occur: ingestion, eye/dermal contact, and inhalation. Each of these possibilities was examined. Exposure and safety risks were assessed with regard to the currently known constituents that are believed to pose potential hazards; VAP, VAM, 2EH, and acetaldehyde. Buchanan concluded that the aerosol sealant did not pose any significant health and safety risks. 


\section{ASHRAE: Rating of Distribution Systems - ASHRAE 152P}

ASHRAE 152P has been developed to the point where it has been published by ASHRAE for public review during May and June 1999. It is expected that the final draft of this standard will be ready by January 2000 . We have also developed a web-based tool for performing $152 \mathrm{P}$ calculations. This tool can be accessed at http://ducts.lbl.gov. This web tool includes many defaults as guides for the uninitiated user that are taken from the appendices of $152 \mathrm{P}$. These defaults are intended to make this web-tool easier to use.

\section{ASTM: Rating of duct sealants and revising duct leakage measurement methods}

We have attended ASTM meetings and corresponded with ASTM to discuss the implementation of an ASTM standard for longevity testing of duct sealants (ASTM (1999b)). A draft of the standard was prepared and voted on by ASTM E6.41 subcommittee members. Several comments were made on this draft which was then revised and will be reballotted later this year.

The current duct leakage test measurement in ASTM E1554 is obsolete. That standard has been rewritten, based on the results of duct leakage test evaluations performed for the last three phases of the current research sponsored by CIEE/CEC, together with input from other ASTM members and the members of ASHRAE SSPC 152P. The new draft of the standard has two leakage test methods: the DeltaQ test and duct pressurization. The standard also includes the benefits and drawbacks of the two methods so that the user can select the most appropriate test method for the test they are performing. For example the DeltaQ test is better for measuring leaky duct systems for HERS testing, but the pressurization tests are more robust for low leakage compliance testing.

\section{References}

ACCA. 1986. Manual J - Load Calculation for Residential Winter and Summer Air Conditioning - Seventh Edition., Air Conditioning Contractors of America (ACCA), Washington, D.C.

ARI. 1999. Electronic Unitary Directory, ARI UD99s V1.2. Air Conditioning and Refrigeration Institute, Arlington, VA.

ASHRAE. 1997. Handbook of Fundamentals. ASHRAE, Atlanta, GA.

ASHRAE. 1999. ASHRAE Standard 152P: Method of Test for Determining the Design and Seasonal Efficiencies of Residential Thermal Distribution Systems (public review draft). ASHRAE, Atlanta, GA.

ASTM. 1999. Draft revision to Standard E-1554 - Determining External Air Leakage of Air Distribution Systems by Fan Pressurization. American Society for Testing and Materials, West Conshohocken, PA.

ASTM. 1999b. Task group draft - Standard Test Method for Longevity Testing of Duct Sealant Methods. American Society for Testing and Materials, West Conshohocken, PA.

Buchanan, C. 1999. Duct Seal Health and Safety Assessment. LBNL 43114

California Energy Commission (CEC). 1998. Low-Rise Residential Alternative Calculation Method Approval Manual for 1998 Energy Efficiency Standards for Low-Rise Residential Buildings, California Energy Commission, Sacramento, California.

Cummings, J.B., Tooley, J.J., Moyer, M. and Dunsmore, R. 1990. Impacts of duct leakage on infiltration rates, space conditioning energy use and peak electrical demand in Florida houses. Proc. 1990 ACEEE Summer Study, Vol. 9, pp.65-76. ACEEE, Washington, DC.

Modera, M.P., 1989. Residential Duct System leakage: Magnitude, Impacts and Potential for reduction. ASHRAE Trans., Vol 95, Part 2, pp.561-569. ASHRAE, Atlanta, GA. 
Modera, M.P., and Wilcox, B.1995. Treatment of residential duct leakage in Title 24 energy efficiency Standards. California Energy Commission Contract Report.

NCDC. 1980. Climatography of U.S., \#81, Monthly Normals of Temperature, Precipitation and Heating and Cooling Degree days 1951-1980. National Climatic Data Center, Federal Building, Asheville, NC.

Palmiter, L. and Francisco, P. 1994. Measured Efficiency of Forced-Air distribution systems in 24 houses. Proc. 1994. ACEEE Summer Study, Vol. 3, pp. 177-187. ACEEE, Washington, DC.

Palmiter, L. and Bond, T., 1992. Impact of mechanical systems on ventilation and infiltration in homes. Proc. 1992 ACEEE Summer Study, Vol. 2, pp.205-216. ACEEE, Washington, DC.

Proctor, J. 1998a. Monitored In-Situ Performance of residential Air-Conditioning Systems. ASHRAE Trans. Vol. 104. Part 1. ASHRAE, Atlanta, GA.

Proctor, J. 1998b. Performance of a Reduced Peak kW Air Conditioner at High Temperatures and Typical Field Conditions. Proc. ACEEE Summer Study on Energy Efficiency in Buildings 1998. Vol. 1 pp.265-274. American Council for an Energy Efficient Economy, Washington, D.C.

Proctor, J. 1997. "Field Measurements of new residential air conditioners in Phoenix, Arizona." ASHRAE Trans. Vol. 103 Part 1. ASHRAE, Atlanta, GA.

Rodriguez, A.G., O'Neal, D.L., Bain, J.A., and Davis, M.A.1995. The Effect of Refrigerant Charge, Duct Leakage, and Evaporator Air Flow on the High Temperature Performance of Air Conditioners and Heat Pumps. Energy Systems Laboratory report for EPRI, Texas A\&M University.

Walker, I.S. 1993. Attic Ventilation, Heat and Moisture Transfer. Ph.D. Thesis, University of Alberta, Alberta, Canada.

Walker, I, Sherman, M., Modera, M., Siegel, J.Dickerhoff, D.1997. Leakage Diagnostics, Sealant Longevity, Sizing and Technology Transfer in Residential Thermal Distribution Systems. CIEE Residential Thermal Distribution Systems Phase V Final Report, October 1997, LBNL Report 41118.

Walker, I., Sherman, M., Siegel, J., Wang, D., Buchanan, C. and Modera, M. 1998. eakage Diagnostics, Sealant Longevity, Sizing and Technology Transfer in Residential Thermal Distribution Systems: Part II. CIEE Residential Thermal Distribution Systems Phase VI Final Report, October 1997, CIEE, Berkeley, CA. LBNL report 42127.

Walker, I., Brown, K., Siegel, J. and Sherman, M. 1998. Saving Tons at the Register. Proc. ACEEE Summer Study, Vol. 1, pp. 367-383. ACEEE, Washington, DC. LBNL report 41957.

Walker, I., Sherman, M., and Siegel, J. 1999. Distribution Effectiveness and Impacts on Equipment Sizing. CIEE Residential Thermal Distribution Systems Transition Phase Final Report. CIEE, Berkeley, CA. LBNL 43724 


\section{Appendix A. Detailed Measurement Results}

\begin{tabular}{|l|c|c|c|c|c|c|}
\hline \multicolumn{5}{|c|}{ Table A1. Pulldown time and temperatures in different locations in the house } \\
\hline \multicolumn{2}{|c|}{ Pulldown Time (minutes) } & \multicolumn{3}{c|}{ Temperatures ( ${ }^{\circ}$ C) } \\
\hline Condition & Thermostat & Master BR & Kitchen & Thermostat & Master BR & Kitchen \\
\hline $\begin{array}{l}\text { Sacramento as } \\
\text { found }\end{array}$ & 239 & 122 & 198 & 24.1 & 21.9 & 23.2 \\
\hline $\begin{array}{l}\text { Sacramento as } \\
\text { found, new } \\
\text { compressor }\end{array}$ & 159 & 64 & 107 & 24.0 & 21.9 & 23.1 \\
\hline $\begin{array}{l}\text { Sacramento } \\
\text { Leaks added }\end{array}$ & 170 & 75 & 92 & 24.0 & 22.1 & 22.7 \\
\hline $\begin{array}{l}\text { Cedar Park as } \\
\text { found }\end{array}$ & 257 & 93 & 266 & 24.0 & 21.0 & 24.2 \\
\hline $\begin{array}{l}\text { Cedar Park as } \\
\text { found, new } \\
\text { compressor }\end{array}$ & 118 & 20 & 123 & 23.2 & 20.3 & 23.1 \\
\hline $\begin{array}{l}\text { Cedar Park } \\
\text { leaks added }\end{array}$ & 94 & 8 & 75 & 23.6 & 22.8 & 25.2 \\
\hline
\end{tabular}

\begin{tabular}{|l|c|c|c|c|c|c|c|c|c|}
\hline \multicolumn{8}{|c|}{ Table A2. Temperatures at different locations in the house during pulldown tests } \\
\hline \multicolumn{1}{|c|}{ Condition } & $\begin{array}{l}\text { Thermostat } \\
{\left[{ }^{\circ} \mathrm{C}\right]}\end{array}$ & $\begin{array}{l}\text { Master } \\
\mathrm{BR}\left[{ }^{\circ} \mathrm{C}\right]\end{array}$ & $\begin{array}{l}\text { Kitchen } \\
{\left[{ }^{\circ} \mathrm{C}\right]}\end{array}$ & $\begin{array}{l}\text { Thermostat } \\
{\left[{ }^{\circ} \mathrm{C}\right]}\end{array}$ & $\begin{array}{l}\text { Master } \\
\mathrm{BR}\left[{ }^{\circ} \mathrm{C}\right]\end{array}$ & $\begin{array}{l}\text { Kitchen } \\
{\left[{ }^{\circ} \mathrm{C}\right]}\end{array}$ & $\begin{array}{l}\text { Thermostat } \\
{\left[{ }^{\circ} \mathrm{C}\right]}\end{array}$ & $\begin{array}{l}\text { Master } \\
\mathrm{BR}\left[{ }^{\circ} \mathrm{C}\right]\end{array}$ & $\begin{array}{l}\text { Kitchen } \\
{\left[{ }^{\circ} \mathrm{C}\right]}\end{array}$ \\
\hline $\begin{array}{l}\text { Sacramento as } \\
\text { found }\end{array}$ & 30 & 26.9 & 28.1 & 28.5 & 26.7 & 25.9 & 27.6 & 26.1 & 25.0 \\
\hline $\begin{array}{l}\text { Sacramento as } \\
\text { found, new } \\
\text { compressor }\end{array}$ & 28.6 & 27.5 & 26.8 & 27.0 & 25.5 & 24.7 & 26.1 & 24.8 & 23.8 \\
\hline $\begin{array}{l}\text { Sacramento } \\
\text { Leaks added }\end{array}$ & 28.1 & 27.0 & 26.9 & 26.7 & 25.1 & 24.9 & 26.0 & 24.4 & 24.1 \\
\hline $\begin{array}{l}\text { Cedar Park as } \\
\text { found }\end{array}$ & 26.6 & 30.1 & 28.0 & 27.8 & 28.6 & 25.5 & 27.3 & 28.2 & 24.7 \\
\hline $\begin{array}{l}\text { Cedar Park as } \\
\text { found, new } \\
\text { compressor }\end{array}$ & No data & No data & No data & 27.6 & 28.4 & 25.2 & 27.0 & 27.7 & 24.4 \\
\hline $\begin{array}{l}\text { Cedar Park } \\
\text { leaks added }\end{array}$ & 24.4 & 26 & 23.6 & 23.6 & 24.5 & 21.4 & 22.9 & 23.7 & 20.7 \\
\hline
\end{tabular}




\begin{tabular}{|c|c|c|c|c|c|c|c|}
\hline \multicolumn{8}{|c|}{ Table A3. Tons At the Register (TAR) } \\
\hline & & \multicolumn{2}{|c|}{. 5 minutes } & \multicolumn{2}{|c|}{30 Minutes } & \multicolumn{2}{|c|}{60 minutes } \\
\hline & & Total & Sensible & Total & Sensible & Total & Sensible \\
\hline $\begin{array}{l}\text { Site and test } \\
\text { conditions }\end{array}$ & $\begin{array}{l}\text { Nominal } \\
\text { Capacity }\end{array}$ & Mean & Mean & Mean & Mean & Mean & Mean \\
\hline $\begin{array}{l}\text { Sacramento, as } \\
\text { found leakage }\end{array}$ & 2 & 3.1 & 1.1 & 3.0 & 1.2 & 2.9 & 1.3 \\
\hline $\begin{array}{l}\text { Sacramento, as } \\
\text { found leakage, } \\
\text { ENERGYSTAR } \\
\text { equipment }\end{array}$ & 2 & 1.9 & 1.3 & 1.7 & 1.3 & 1.6 & 1.3 \\
\hline $\begin{array}{l}\text { Sacramento, } \\
\text { added leaks, } \\
\text { ENERGYSTAR } \\
\text { equipment }\end{array}$ & 2 & 1.4 & 1.0 & 1.3 & 1.0 & 1.4 & 1.2 \\
\hline $\begin{array}{l}\text { Cedar Park, as } \\
\text { found leakage }\end{array}$ & 3 & 2.8 & 1.2 & 2.0 & 1.3 & 1.9 & 1.4 \\
\hline $\begin{array}{l}\text { Cedar Park, as } \\
\text { found leakage, } \\
\text { ENERGYSTAR } \\
\text { equipment }\end{array}$ & 3 & No data & No data & 2.2 & 1.4 & 2.0 & 1.4 \\
\hline $\begin{array}{l}\text { Cedar Park, } \\
\text { added leaks, } \\
\text { ENERGYSTAR } \\
\text { equipment }\end{array}$ & 3 & 2.8 & 1.4 & 2.1 & 1.4 & 2.0 & 1.4 \\
\hline
\end{tabular}

Table A4. Capacity at the Indoor Coil

\begin{tabular}{|c|c|c|c|c|c|c|}
\hline & \multicolumn{2}{|c|}{5 minutes } & \multicolumn{2}{|c|}{30 minutes } & \multicolumn{2}{|c|}{60 minutes } \\
\hline & Total & Sensible & Total & Sensible & Total & Sensible \\
\hline Condition & $\mathrm{KW}$ & $\mathrm{kW}$ & $\mathrm{kW}$ & $\mathrm{kW}$ & $\mathrm{kW}$ & $\mathrm{kW}$ \\
\hline $\begin{array}{l}\text { Sacramento as } \\
\text { found }\end{array}$ & 12.3 & 4.8 & 11.7 & 5 & 11.5 & 5.2 \\
\hline $\begin{array}{l}\text { Sacramento as } \\
\text { found, new } \\
\text { compressor }\end{array}$ & 7.6 & 5.17 & 6.9 & 5.4 & 6.7 & 5.5 \\
\hline $\begin{array}{l}\text { Sacramento Leaks } \\
\text { added }\end{array}$ & 6.1 & 4.5 & 5.6 & 4.7 & 5.5 & 4.7 \\
\hline $\begin{array}{l}\text { Cedar Park as } \\
\text { found }\end{array}$ & 12.1 & 6 & 9.5 & 6.9 & 9.2 & 7.1 \\
\hline $\begin{array}{l}\text { Cedar Park as } \\
\text { found, new } \\
\text { compressor }\end{array}$ & No data & No data & 9.9 & 7.2 & 9.7 & 7.4 \\
\hline $\begin{array}{l}\text { Cedar Park leaks } \\
\text { added }\end{array}$ & 11.8 & 6.6 & 9.3 & 6.7 & 9.0 & 6.8 \\
\hline
\end{tabular}




\begin{tabular}{|l|c|c|c|c|c|c|}
\hline \multicolumn{7}{|c|}{ Table A5. Equipment Coefficient of Performance (COP) } \\
\hline \multicolumn{7}{|c|}{ Sensible } \\
\hline Condition & 5 minutes & 30 minutes & 60 minutes & 5 minutes & 30 minutes & 60 minutes \\
\hline $\begin{array}{l}\text { Sacramento as } \\
\text { found }\end{array}$ & 1.7 & 1.8 & 1.9 & $\star$ & & \\
\hline $\begin{array}{l}\text { Sacramento as } \\
\text { found, new } \\
\text { compressor }\end{array}$ & 2.2 & 2.4 & 2.4 & 3.3 & 3.0 & 2.9 \\
\hline $\begin{array}{l}\text { Sacramento } \\
\text { Leaks added }\end{array}$ & 2.2 & 2.2 & 2.2 & 2.9 & 2.7 & 2.6 \\
\hline $\begin{array}{l}\text { Cedar Park as } \\
\text { found }\end{array}$ & 1.6 & 1.9 & 1.9 & 3.2 & 2.6 & 2.5 \\
\hline $\begin{array}{l}\text { Cedar Park as } \\
\text { found, new } \\
\text { compressor }\end{array}$ & Poor data & 1.9 & 2.0 & Poor data & 2.7 & 2.6 \\
\hline $\begin{array}{l}\text { Cedar Park } \\
\text { leaks added }\end{array}$ & 1.8 & 1.7 & 1.8 & 3.1 & 2.4 & 2.3 \\
\hline
\end{tabular}

* - poor RH measurements mean that total COP cannot be accurately estimated.

\begin{tabular}{|l|c|c|c|c|}
\hline & 5 minutes & 30 minutes & 60 minutes & $\begin{array}{l}\text { Air Handler fan } \\
\text { power as fraction } \\
\text { of total power } \\
\text { consumption }\end{array}$ \\
\hline \multicolumn{1}{|c|}{ Condition } & $\mathrm{KW}$ & $\mathrm{kW}$ & $\mathrm{KW}$ & 0.20 \\
\hline $\begin{array}{l}\text { Sacramento as } \\
\text { found }\end{array}$ & 2.9 & 2.9 & 2.8 & $0.30^{\prime}$ \\
\hline $\begin{array}{l}\text { Sacramento as } \\
\text { found, new } \\
\text { compressor }\end{array}$ & 2.4 & 2.4 & 2.3 & 0.30 \\
\hline $\begin{array}{l}\text { Sacramento Leaks } \\
\text { added }\end{array}$ & 2.1 & 2.1 & 3.7 & 0.20 \\
\hline $\begin{array}{l}\text { Cedar Park as } \\
\text { found }\end{array}$ & 3.7 & 3.7 & 3.7 & 0.20 \\
\hline $\begin{array}{l}\text { Cedar Park as } \\
\text { found, new } \\
\text { compressor }\end{array}$ & Poor data & 3.7 & 3.9 & 0.15 \\
\hline $\begin{array}{l}\text { Cedar Park leaks } \\
\text { added }\end{array}$ & 3.8 & 3.9 & & \\
\hline
\end{tabular}

1 - Large variation indicating a variable speed compressor 


\begin{tabular}{|l|c|c|c|c|c|c|}
\hline \multicolumn{7}{|c|}{ Table A7. Total System Coefficient of Performance (COP) } \\
\hline & \multicolumn{2}{|c|}{ Sensible } & \multicolumn{3}{c|}{ Total } \\
\hline Condition & 5 minutes & 30 minutes & 60 minutes & 5 minutes & 30 minutes & 60 minutes \\
\hline $\begin{array}{l}\text { Sacramento as } \\
\text { found }\end{array}$ & 1.4 & 1.5 & 1.6 & 3.9 & 3.8 & 3.8 \\
\hline $\begin{array}{l}\text { Sacramento as } \\
\text { found, new } \\
\text { compressor }\end{array}$ & 1.9 & 2.0 & 2.1 & 2.8 & 2.5 & 2.6 \\
\hline $\begin{array}{l}\text { Sacramento } \\
\text { Leaks added }\end{array}$ & 1.7 & 1.7 & 2.0 & 2.4 & 2.1 & 2.4 \\
\hline $\begin{array}{l}\text { Cedar Park as } \\
\text { found }\end{array}$ & 1.1 & 1.2 & 1.3 & 2.7 & 1.9 & 1.8 \\
\hline $\begin{array}{l}\text { Cedar Park as } \\
\text { found, new } \\
\text { compressor }\end{array}$ & Poor data & 1.4 & 1.4 & Poor data & 2.1 & 2.0 \\
\hline $\begin{array}{l}\text { Cedar Park } \\
\text { leaks added }\end{array}$ & 1.4 & 1.3 & 1.3 & 2.6 & 1.9 & 1.9 \\
\hline
\end{tabular}

\begin{tabular}{|l|c|c|c|c|c|c|}
\hline \multicolumn{7}{|c|}{ Table A8. Delivery Effectiveness } \\
\hline & \multicolumn{7}{|c|}{ Sensible } & \multicolumn{3}{c|}{ Total } \\
\hline Condition & 5 minutes & 30 minutes & 60 minutes & 5 minutes & 30 minutes & 60 minutes \\
\hline $\begin{array}{l}\text { Sacramento as } \\
\text { found }\end{array}$ & 0.85 & 0.85 & 0.84 & 0.88 & 0.89 & 0.88 \\
\hline $\begin{array}{l}\text { Sacramento as } \\
\text { found, new } \\
\text { compressor }\end{array}$ & 0.86 & 0.83 & 0.85 & 0.88 & 0.85 & 0.87 \\
\hline $\begin{array}{l}\text { Sacramento } \\
\text { Leaks added }\end{array}$ & 0.78 & 0.77 & 0.90 & 0.80 & 0.79 & 0.90 \\
\hline $\begin{array}{l}\text { Cedar Park as } \\
\text { found }\end{array}$ & 0.69 & 0.67 & 0.67 & 0.82 & 0.75 & 0.74 \\
\hline $\begin{array}{l}\text { Cedar Park as } \\
\text { found, new } \\
\text { compressor }\end{array}$ & Poor data & 0.78 & 0.74 & Poor data & Poor data & Poor data \\
\hline $\begin{array}{l}\text { Cedar Park } \\
\text { leaks added }\end{array}$ & 0.77 & 0.75 & 0.75 & 0.85 & 0.80 & 0.80 \\
\hline
\end{tabular}

\begin{tabular}{|l|c|c|c|c|c|c|c|c|c|}
\hline \multicolumn{8}{|c|}{ Table A9 Key Temperatures and Enthalpies for Calculating System Performance } \\
\hline \multicolumn{1}{|c|}{ Condition } & $\begin{array}{l}\text { Tout } \\
\left({ }^{\circ} \mathrm{C}\right)\end{array}$ & $\begin{array}{l}\text { hreturn } \\
(\mathrm{kJ} / \mathrm{kg})\end{array}$ & $\begin{array}{l}\text { Tattic } \\
\left({ }^{\circ} \mathrm{C}\right)\end{array}$ & $\begin{array}{l}\text { Tout } \\
\left({ }^{\circ} \mathrm{C}\right)\end{array}$ & $\begin{array}{l}\text { hreturn } \\
(\mathrm{kJ} / \mathrm{kg})\end{array}$ & $\begin{array}{l}\text { Tattic } \\
\left({ }^{\circ} \mathrm{C}\right)\end{array}$ & $\begin{array}{l}\text { Tout } \\
\left({ }^{\circ} \mathrm{C}\right)\end{array}$ & $\begin{array}{l}\text { hreturn } \\
(\mathrm{kJ} / \mathrm{kg})\end{array}$ & $\begin{array}{l}\text { Tattic } \\
\left({ }^{\circ} \mathrm{C}\right)\end{array}$ \\
\hline $\begin{array}{l}\text { Sacramento as } \\
\text { found }\end{array}$ & 36.9 & 61.4 & 60.2 & 36.5 & 56.1 & 57.5 & 35.8 & 53.6 & 55.0 \\
\hline $\begin{array}{l}\text { Sacramento as } \\
\text { found, new } \\
\text { compressor }\end{array}$ & 32.2 & 57.4 & 56 & 32.0 & 52.2 & 53.4 & 31.9 & 49.6 & 50.6 \\
\hline $\begin{array}{l}\text { Sacramento Leaks } \\
\text { added }\end{array}$ & 32.8 & 55.7 & 53.6 & 32.6 & 51.8 & 50.9 & 31.9 & 49.6 & 48.1 \\
\hline $\begin{array}{l}\text { Cedar Park as } \\
\text { found }\end{array}$ & 33.7 & 54.5 & 53.8 & 34.0 & 48.9 & 54.4 & 34.3 & 46.7 & 53.1 \\
\hline $\begin{array}{l}\text { Cedar Park as } \\
\text { found, new } \\
\text { compressor }\end{array}$ & $\begin{array}{l}\text { Poor } \\
\text { data }\end{array}$ & $\begin{array}{l}\text { Poor } \\
\text { data }\end{array}$ & 38.8 & 33.4 & 48.8 & 48.9 & 33.8 & 46.3 & 50.6 \\
\hline $\begin{array}{l}\text { Cedar Park leaks } \\
\text { added }\end{array}$ & 27.4 & 41.8 & 37.1 & 27.1 & 46.4 & 37.0 & 27.2 & 43.6 & 35.8 \\
\hline
\end{tabular}

1- outside air dry bulb temperature

2- enthalpy of air in return

3- attic air dry bulb temperature 


\section{Appendix B. Flowchart for REGCAP Model}



